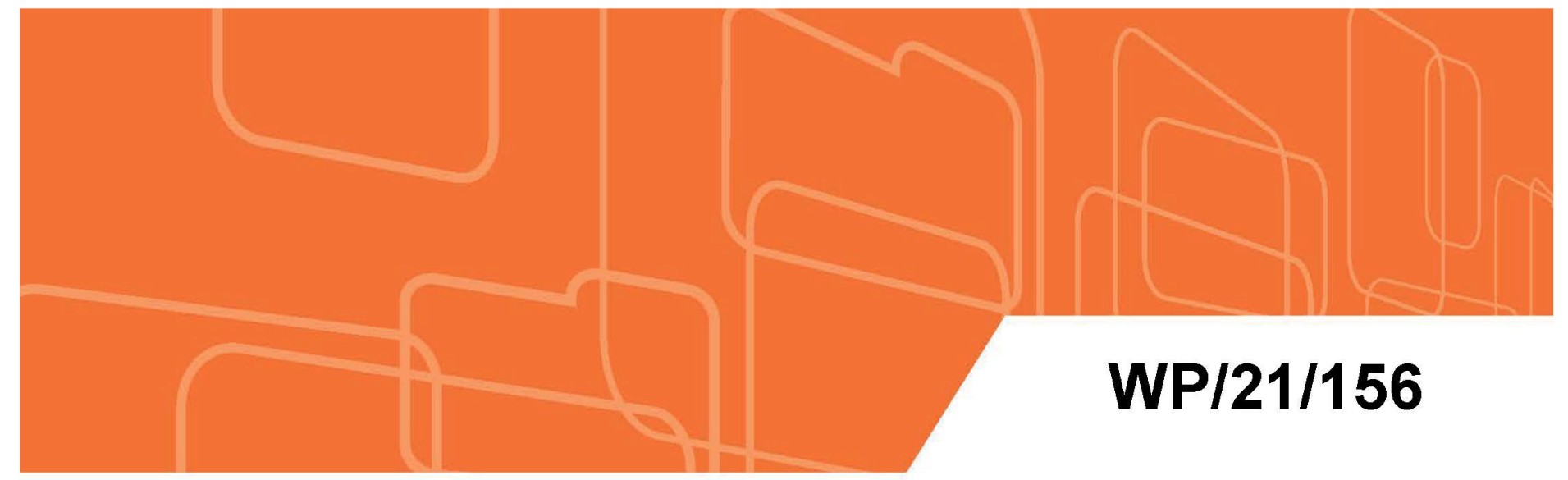

IMF Working Paper

\title{
Are Climate Change Policies Politically Costly?
}

by Davide Furceri, Michael GansImeier and Jonathan D. Ostry

IMF Working Papers describe research in progress by the author(s) and are published to elicit comments and to encourage debate. The views expressed in IMF Working Papers are those of the author(s) and do not necessarily represent the views of the IMF, its Executive Board, or IMF management. 


\title{
IMF Working Paper
}

Asia and Pacific Department

\section{Are Climate Change Policies Politically Costly?}

\section{Prepared by Davide Furceri, Michael Ganslmeier and Jonathan D. Ostry ${ }^{1}$}

Authorized for distribution by Jonathan D. Ostry

June 2021

\section{IMF Working Papers describe research in progress by the author(s) and are published to} elicit comments and to encourage debate. The views expressed in IMF Working Papers are those of the author(s) and do not necessarily represent the views of the IMF, its Executive Board, or IMF management.

\begin{abstract}
Are policies designed to avert climate change (Climate Change Policies, or CCPs) politically costly? Using data on governmental popular support and the OECD's Environmental Stringency Index, we find that CCPs are not necessarily politically costly: policy design matters. First, only market-based CCPs (such as emission taxes) generate negative effects on popular support. Second, the effects are muted in countries where non-green (dirty) energy is a relatively small input into production. Third, political costs are not significant when CCPs are implemented during periods of low oil prices, generous social insurance and low inequality.
\end{abstract}

JEL Classification Numbers: D72; J65; L43; L51; O43; O47; P16.

Keywords: Climate change policies; climate change; political support; political cost. E-Mail Addresses: DFurceri@,imf.org; michael.ganslmeier@spi.ox.ac.uk; JOstry@,1imf.org

\footnotetext{
${ }^{1}$ Davide Furceri (dfurceri@imf.org) is Deputy Division Chief in the Asia and Pacific Department of the IMF; Michael Ganslmeier (michael.ganslmeier@spi.ox.ac.uk) is a DPhil Student at the University Oxford and Visiting Research Fellow at University College London; Jonathan D. Ostry (jostry@imf.org) is Deputy Director of the Asia and Pacific Department of the IMF and a Research Fellow at the Center for Economic Policy Research (CEPR) in London. We thank Jean Chateau, Ian Perry, Lukas Lehner, Orkun Saka, Gregor Schwerhoff, Tim Vlandas and Jeromin Zettelmeyer as well as participants and discussants from the IMF Surveillance Meeting and the DSPI Research Group Meeting at Oxford for their valuable comments and suggestions. We are grateful to Connor Kinsella for excellent editorial assistance.
} 


\section{Contents}

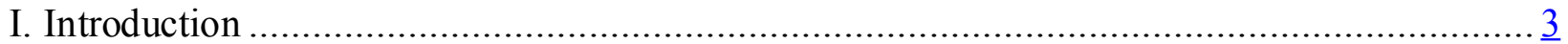

II. The Political Economy of Climate Change Policies ........................................................ $\underline{6}$

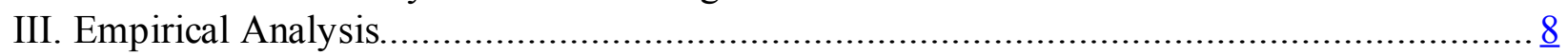

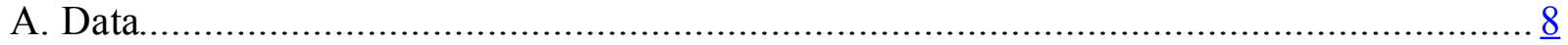

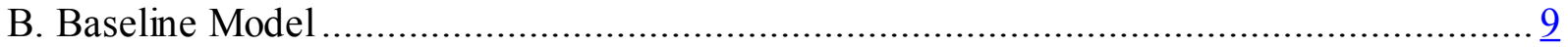

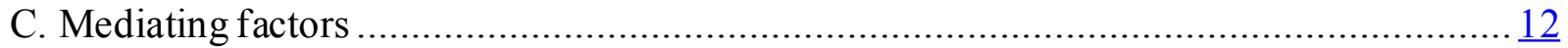

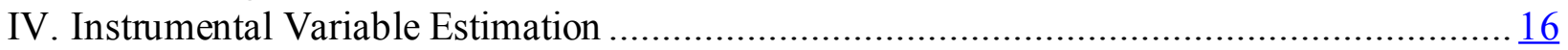

A. IV Estimation of the Baseline Model ..................................................................

B. IV Estimation of the Interaction Models............................................................. 19

V. Policy Implications and Conclusions ....................................................................

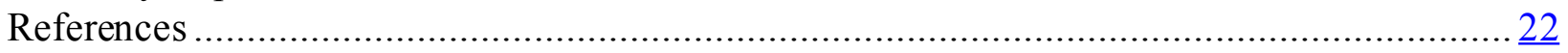

Tables

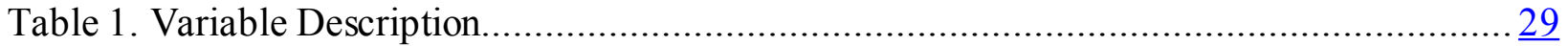

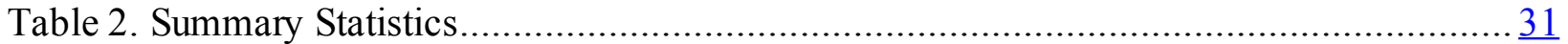

Table 3. The effect of EPS changes on popular support..................................................

Table 4. The effect of market-based EPS changes on popular support....................................

Table 5. The effect of non-market-based EPS changes on popular support............................. $\underline{36}$

Table 6 . The effect of EPS changes on popular support mediated by fuel prices, share of dirty energy industries and initial level of EPS..................................................................

Table 7. The effect of EPS changes on popular support mediated by inco me shares................. $\underline{38}$

Table 8. The effect of EPS changes on popular support using instrumental variable regressions $\underline{40}$

Table 9. Validity of IV (1). effect of instruments on popular support ................................... 41

Table 10. Validity of IV (2). correlation of instruments on baseline residuals......................... 42

Table 11. Validity of IV (3). robustness of IV estimation with additional controls.................... 43

Table 12-1. The effect of EPS changes on popular support mediated by fuel prices (IV) ........... 44

Table 12-2. The effect of EPS changes on popular support mediated by share of dirty energy

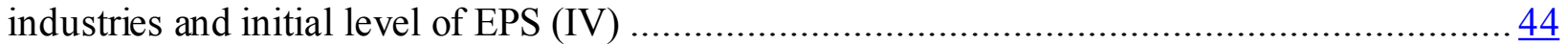

Table 12-4. The effect of EPS changes on popular support mediated by income shares (IV)..... 45

Table 12-5. The effect of EPS changes on popular support mediated by inequality (IV)........... $\underline{46}$

Table 12-6. The effect of EPS changes on popular support mediated by social expenditure (IV) $\underline{46}$

Table A1. The effect of EPS changes on popular support - WALS and BMA......................... 47

Table A2. The effect of EPS changes on vote share ..................................................... 48

Table A3. The effect of EPS changes on popular support mediated by social expenditure types $\underline{49}$

Table A4. The effect of EPS changes on vote share using instrumental variable regressions..... $\underline{50}$

Table A5. The effect of EPS changes on popular support mediated by ideology....................... 51 


\section{INTRODUCTION}

There are few issues that have sparked more attention across the globe than how to avoid the environmental and human catastrophe that climate change is inflicting on our planet. In the period leading up to the pandemic, what started as a school strike by a sixteen-year old in Sweden has spurred unprecedented advocacy by an entire generation of policies to fundamentally change course in the pursuit of far-reaching climate changes policies (CCPs). But even in the wake of massive public protests and an ambitious agenda since the 2015 Paris Agreement, the hesitancy of politicians is remarkable. This is disturbing.

Why? First, because the evidence on the economics of climate change is very clear that the long-term costs of unmitigated global warming will outweigh the short-term adjustment costs from mitigation (Stern, 2006). Although economists expect that poor countries will be hit the most (Diffenbaugh and Burke, 2019; Dell et al., 2012), industrial countries are estimated to suffer losses of $1 \frac{1}{2}-2$ percent of GDP if global temperatures rise 2-4 degrees Celsius by 2100 (Hsiang et al., 2017). Kahn et al. (2019) project that unmitigated climate change will reduce global real GDP per capita by more than 7 percent by the end of the century. Burke et al. (2015) shows that economic costs are increasing in time because greater accumulation of emissions in the atmosphere requires greater interventions to stabilize global temperatures in the future; moreover, unmitigated global warming would likely lead to global GDP declining by up to one quarter by 2100 (IMF, 2019).

Second, the politics of climate change has also become more favorable to CCPs. In the last decades, the number of green parties has increased in many advanced democracies (Dolezal, 2010). Because green parties (which possess issue ownership on CCPs) are a threat to many non-green parties, it seems likely that mainstream parties would adopt green issues in their manifestos (Meguid, 2005; Spoon et al., 2014; Green-Pedersen and Mortensen, 2010). In addition, with median voters greener over time, there is a re-positioning of mainstream parties in this same direction (Ezrow et al., 2010; Adams et al., 2006). Thus, from a political-party competition perspective, the growing salience of green parties in the landscape should make the adoption of CCPs more likely.

Third, public concerns about climate change have increased in many industrial countries (PEW Research Center, 2019). Among other reasons, this is driven by the increasing number of extreme weather phenomena and natural disasters in the last decade 
(EMDAT, 2020) which make people more risk averse about climate change (Herrnstadt and Muehlegger, 2014; Bird et al., 2014; Welsch and Biermann, 2014). Social instability, global protests, rising environmental awareness and the rise of pro-environmental NGOs are also bringing green issues to the forefront of the political agenda (Hsiang and Burke, 2014; Liu et al., 2011; Steves and Teytelboym, 2013).

Despite these push factors, governments remain hesitant despite the availability of effective mitigation instruments (Weitzman, 1974; McKibbin and Wilcoxen, 2002; Aldy et al., 2003; Li and Lin, 2013; Carl and Fedor, 2016; Akerlof et al., 2019). While political costs of reform is a mainstay of the political-economy literature (Alesina and Drazen, 1991; Drazen and Grilli, 1993; Persson and Tabellini, 2000; Tsebelis, 2002; Alesina et al., 2006; Alesina et al. 2020a,b), the tie-in with climate policies has been less systematically investigated. ${ }^{2}$ With the present paper, we aim to fill this void.

Our paper contributes to the literature on the political economy of CCPs in several aspects. First, we estimate the average effect of CCPs on support for the government implementing them (governmental support for short) — where CCPs are proxied by the OECD’s Environmental Policy Stringency (EPS) indicators (Botta and Kozluk, 2014) and governmental support is proxied by the "Index of Popular Support" produced by the International Country Risk Guide (ICRG) from public opinion polls in a sample of 34 advanced and emerging market economies for the period 2001-2015. Our results show that CCPs reduce popular support on average, but this mainly reflects the impact of market-based policy measures, such as emission taxes, rather than non-market-based measures, such as emission limits. This result strikes us as central given that economists see Pigouvian taxation as the first-best corrective tool for carbon emissions (Jenkins, 2014; Goulder and Parry, 2008; Goulder et al., 2019; Stiglitz, 2019; IMF, 2019). Although often second-best options,

\footnotetext{
${ }^{2}$ While some studies focus on the political economy of CCPs, empirical a nalyses test ing for political costs are missing from the litera ture. For instance, Savocool et al. (2015) use a case study approach covering eight countries and discuss how economic, social and political tra de-offs led to insufficient climate change adaptation efforts in the past. In a similar vein, Klenert et al. (2018a) review the economic and political science literature on the obstacles to carbon pricing and argue for revenue recycling mechanisms to reduce distributional concerns. Thesenotions are in line with the earlier theoretical model in Klenert et al. (20158b), in which the authors formally show how public revenues - ra ised through emission taxation - can be re-directed to adversely-affected households and firms and in this way are able to reduce the efficiency-equity trade-off.
} 
nonmarket-based measures are still efficient tools to combat climate change (IMF, 2019a) while being more politically viable (IMF, 2019).

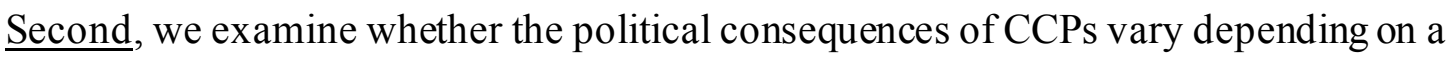
number of mediating factors. We show that political costs are larger: (i) in times of high fuel prices; (ii) for countries with a high input share of dirty energy in mining and production; (iii) when CCPs are adopted when inequality is high; and (iv) when social expenditures do not compensate the losers from CCPs. Remarkably, in the counterfactual to all of these situations, the political cost of CCPs is not statistically different from zero.

$\underline{\text { Third, }}$ we propose an identification strategy that enables us to confirm our baseline estimates and draw causal conclusions. Beyond omitted variable bias, reverse causality is the key methodological problem in attempting to link policy change with popular support outcomes. On the one hand, the adoption of CCPs requires political support (Alesina et al. 2020) which would imply a positive effect of our dependent variable on our explanatory variable. ${ }^{3}$ In this case, the OLS estimates would under-estimate the causal effect. On the other hand, an unpopular government may implement CCPs because it has nothing to lose. Additionally, events such as natural disasters may shift policy preferences and heighten incentives for governments to adopt stricter CCPs. In both cases, OLS estimates would overstate the political costs of CCPs. ${ }^{4}$

To address these problems, we use an Instrumental Variable (IV) approach that exploits cross-sectional variation in a country's likelihood to implement CCPs. To do this, we use an interaction between a time-varying global and a country-based geographical term. With the global term, we exploit the time variation in implementing CCPs through a variable that proxies for the "policy pressure" that climate change induces at the global level. Here, we use the occurrence and damage of global extreme weather events, which can be assumed to be exogenous with respect to country's levels of government support. The country-specific term consists of geographical indicators which determine the vulnerability of a country towards climate change. For instance, we use the length of the coastline as a proxy for vulnerability to

\footnotetext{
${ }^{3}$ Alternatively, governments with weak popular support may delay the implementation of structural policies because of the fear of losing elections.

${ }^{4}$ There can also be measurement error on both sides which would lea do standard attenuation bias.
} 
rising sea levels or the urban extent in coastal zones. It is reasonable to assume that such geographical indicators are randomly distributed and do not affect general levels of government support. The analysis also controls for country and time fixed effects and can therefore be seen as a differences-in-differences approach. Overall, our results show that endogeneity in the OLS estimator indeed is likely to result in underestimation of the true causal effect. These results are robust to various instrument and validity tests. Since establishing causality is a challenging undertaking in macroeconomic setups (Nakamura and Steinson, 2018), our IV approach can be a promising avenue for future analysis studying the effect of CCPs.

The paper is structured as follows. In the next section, we review the literature on CCPs, paying attention to the allocation of costs and benefits from stricter environmental regulation, the challenges of international agreements, and strategies on the mitigation of political costs. In section III, we present the data, outline our empirical approach and discuss the baseline results. Section IV presents the Instrumental Variable approach and results. Section V concludes with some implications for policymakers in advanced economies.

\section{The Political Economy of Climate Change Policies}

There are parallels between the literature on the political economy of structural reforms and the political economy of environmental policies. Both types of reform are subject to resistance and a lack of political will despite the fact that they are welfare maximizing in the long run. In seminal contributions by Alesina and Drazen (1991), Drazen and Grilli (1993), Persson an d Tabellini (2000) and Tsebellis (2002), the reform process is modelled as a function of veto players who are required to distribute the benefits and costs in a way that satisfies all of them. ${ }^{5}$

This approach applies also to environmental policies. On the one hand, short-term adjustments costs for the economy from CCPs are significant, while significant benefits materialize only in the very long run. ${ }^{6}$ What constrains the political will even further is that the benefits of CCPs are not directly observable because they materialize in the absence of

\footnotetext{
${ }^{5}$ Alesina et al. (2020a) find that domestic (product and labor market) and external (tra de and capital) structural reforms tend to reduce the vote share of the incumbent's party, especially when implemented close to elections.

${ }^{6}$ In the shorter term, there could be some benefits from carbon pricing including carbon tax revenues and reductions in a ir pollution and associated mortality.
} 
environmental damage. On the other hand, CCPs put a large burden of the adjustment on a few stakeholders, while the benefits from climate protection are distributed widely (Stockes, 2015; Tvinnereim and Iversflaten, 2016). In addition, the regressive nature of CCPs in many countries heighten inequality concerns (Goulder et al., 2019; Stiglitz, 2019; Rojas-Vallejos and Lastuka, 2020). This is especially so for market-based instruments such as emission taxes. Concentration of costs creates strong interest groups against change, while benefit dispersion diffuses support.

Beyond national considerations, environmental protection has always been hostage to the political agenda at the international level. Enforceable solutions are hampered by a dearth of sanctioning mechanisms, and CCP agreements are exposed to ex-post deviations by free-riding countries. A free-riding country gains competitive advantage against a complying country. For instance, the adoption of stricter climate change policies can incentivize multinational firms to relocate their production processes to regions with lower levels of environmental (Koch and Basse Mama, 2019). This constellation of national interests can induce a race-to-the-bottom. In addition, climate change is expected to elevate international economic inequalities further. The Center for Global Development (2015) estimates that 79 percent of global carbon emission from 1980 to 2011 have been generated by developed countries, but these countries are not the ones that struggle most from climate change today (Eckstein et al., 2020). Thus, those most responsible for climate change are precisely those who have not borne much of the cost. International agreements have to contend with achieving a political equilibrium by re-ordering the incentive structures of countries in a way that makes pollution economically unattractive.

In general, CCPs and other structural reforms - by changing the status quo - are likely to be accompanied by distributional consequences - winners and losers (Ostry et al., 2019; Ostry et al., 2020; Markkanen and Anger-Kraavi, 2019). In the realm of CCPs, such policies will make certain products more costly - either directly through taxation or indirectly through increasing production costs (Rao, 2013). Although price increases for oil and gas prices matter to all economic agents, they tighten the budget constraints especially for the poor. This regressivity is a common argument against CCPs and a source of political opposition (Metcalf, 2009; Habla and Roeder, 2017; Goulder et al., 2019). While certain instruments can be designed in a progressive manner, this is not applicable to all types of measures. Thus, when this is not possible, targeted redistributive policies or timing CCPs to periods when energy costs are low, as now, can help to relax pressures on the budget constraints of the poor, and thereby mitigate political costs. 
CCPs have negative side effects for certain industries (Steves and Teytelboym, 2013; Fankhaeser et al., 2008). Although new employment opportunities created by CCPs could mitigate job displacements to some degree (IMF, 2019; IMF, 2020), the adjustment costs would nevertheless be salient in the short run. This is especially the case for the old, and for employees with specialized industry-specific capital or low educational levels (OECD, 2012; Guivarch et al., 2011). Given these considerations, it is not surprising that employees in adversely affected sectors have been vocal against stricter CCPs (Tvinnereim and Iversflaten, 2016). One way to reduce such opposition is for governments to increase targeted assistance programs for certain risk groups (i.e. the unemployed, the elderly), and to devote more resources to training and active labor market programs in sectors that are hurt by CCPs (dirty sectors).

\section{EMPIRICAL ANALYSIS}

This section examines empirically whether governments ought to fear the adoption of CCPs and, if so, whether the political consequences differ across type s of CCP. In a further step, we investigate how political costs can be militated by judicious choice of timing and by complementary measures to mitigate associated rises in inequality.

\section{A. Data}

We use the Environmental Policy Stringency (EPS) indicators constructed by the OECD (Botta and Kozluk, 2014). These data are the most comprehensive available source for policy measures across countries (28 OECD and six BRICS countries) and time (1990-2015) ${ }^{7}$. The dataset helpfully provides a breakdown by instrument type. The EPS data will specifically allow us to test the effect of different instruments - scaled from 0 (not stringent at all) to 6 (very stringent) relative to an overall aggregate index consisting of both market-based and non-market-based measures. Here, market-based measures include instruments such as taxation on emissions, trading schemes and feed-in tariffs, while non-market-based indicators capture legislation on emission limits and R\&D subsidies, among others.

\footnotetext{
${ }^{7}$ One concern might be that environment legislation is a dopted at the supranational level such as the European Union. This would be problematic for our empirical a nalysis as national governments may then not directly responsible for the stricter environmental regula tion. Despite this potential concern, it is noteworthy that substantial cross-country variation exists within the EU and environmental policymaking takes place at the national level.
} 
We use a measure of governmental popular support constructed by the International Country Risk Guide (ICRG, 2020) to gauge political cost. The data cover all countries of interest on an annual basis from 2001 onwards. The support measure is a sub-indicator of the overall government stability score, which assess es the government's ability to carry out its declared program(s), and its ability to stay in office. The indicator ranges between 0 (very high risk) and 4 (very low risk). The annual frequency of the data is key to correctly associate the implementation of CCPs with political outcomes. Finally, the indicator of popular support is strongly correlated with other measures of political strength, such as the vote share of the incumbent party at election time and the probability that the leader of the party gets re-elected (Alesina et al. 2020a). Because of the wide coverage comprising 31 countries over the period $2001-15$, the dataset affords the opportunity to assess countries that are, in sum, responsible for 43 percent of total global carbon emissions (Muntean et al., 2018). Tables 1 and 2 present an overview and summary statistics for all variables.

\section{B. Baseline Model}

In the baseline specification, we regress popular support of the incumbent on the change in the overall EPS indicator. We use policy changes (instead of levels) based on our prior about the well-documented status-quo bias of voters and path dependency obstacles towards institutional change (Samuelson and Zeckhauser, 1988; Fernandez and Rodrik, 1991; Pierson, 1996). We test how the resistance of voters towards policy change is a threat to the popularity of the government.

$$
y_{i, t}=\beta \Delta E P S_{i, t}+\theta X_{i, t}+\alpha_{i}+\gamma_{t}+\epsilon_{i, t}
$$

where $y$ is the popular support for the incumbent and $\triangle E P S$ the change in the EPS indicator. Beyond including country $\left(\alpha_{i}\right)$ and year fixed effects $\left(\gamma_{t}\right)$ to control for country- and timespecific unobserved factors and limit omitted variable bias, the specification includes various economic, political and demographic indicators $X$. Specifically, we control for fiscal deficit as percentage of GDP (OECD), the share of the elderly (65+) as percentage of population (OECD), real GDP growth rate (World Bank), unemployment rate (World Bank), consumer 
price index (OECD), lagged government's vote share (Alesina et al., 2020a), tax revenue as percentage of GDP (World Bank), and numerous economic reform indicators by Alesina et al. (2020a) covering financial, labor and product market policy domains.

The inclusion of these variables is based on well-established streams in the economic literature related to economic voting, political capabilities and structural reforms. For instance, by controlling for tax revenue, we take account of the empirical finding that voters oppose taxes in general ${ }^{8}$ (Alesina et al. 2020b). Beyond these baseline controls, we have tested how the inclusion of further covariates related to political systems changes the effect of our main variables of interest. Our results are robust towards the inclusion of the following variables: ideology of the incumbent, government fractionalization, legislative strength, type of the political system (presidential/assembly/parliamentary), number of years left in current term, margin of majority, Herfindal index of the opposition, democratic accountability index, bureaucratic quality index, civil disorder index, income tax wedge, net household income (level and growth rate) and share of green parties in parliament. While we do not report the single estimations due to space constraints, Table A1 provides model-averaging estimates obtained considering all these variables and using the Weighted Average Linear Squared (WALS) developed by Magnus, Powell, and Prufer (2010), and Bayesian Model Averaging (BMA) developed by Fernandez, Ley and Steel (2001). As the results show, the significant negative effect of CCP is robust to model uncertainty concerns. Since our results are robust to inclusion and exclusion of various sets of controls, we use the specification in Table 3 column 1 as our baseline for the subsequent estimations.

In line with our theoretical expectation, increasing environmental policy stringency has significantly negative and sizeable effects on the popular support for the government (Table 3). A major change in CCPs - equivalent to an increase in the EPS indicator from the $25^{\text {th }}$ to the $75^{\text {th }}$ percentile of the EPS distribution - is found to reduce popular support by about 10 percent. The statistical significance of the results is robust to alterative sets of controls and the magnitude of the coefficients does not change with model specification. Moreover, the cost of implementing stricter CCPs also holds when we use de facto measures of government popularity such the vote share of the incumbent government coalition at the

\footnotetext{
${ }^{8}$ The results remain unchanged if we use the change in tax revenue as control variable instead of the levels.
} 
elections as dependent variable (Table A2). In particular, the results, based on much smaller sample of 108 observations, suggest that a major change in CCPs-equivalent to an increase in the EPS indicator from the $25^{\text {th }}$ to the $75^{\text {th }}$ percentile of the EPS distribution - reduces the vote share of the government coalition by more than 7 percentage points.

In line with previous findings of the literature (see Alesina et al. 2020 and references therein), we also find that better economic conditions, higher deficits and lower inflation are associated with higher political support. We find that the level of popular support its typically larger in countries with an older share of the population as age tends to be positively associated with voting for the incumbent at the individual level (De Vries and Giger, 2014).

To understand whether different policy instruments have heterogenous effects on government popular support, we re-estimate the baseline specification for each subcomponent of the EPS indicator. The literature portrays taxes on emissions as the most effective tool to reduce global greenhouse gases (Jenkins, 2014; Goulder and Parry, 2008; Goulder et al., 2019; Stiglitz, 2019; IMF, 2019). At the same time, carbon taxes play only a limited role in national environmental legislation (Beiser-McGrath and Bernauer, 2019; Carattini et al., 2018). Possibly different political consequences across types of CCPs thus seems to be of the essence.

The results suggest important differences between market-based and nonmarketbased instruments. Market-based measures, and especially taxes on emissions, are broadly consistent with the baseline results pointing to negative consequences on governmental support (Table 4). In contrast, non-market-based measures are typically not statistically significant (Table 5). One interpretation is that price mark-ups are more visible to consumers than supply limits. The fact that households are constantly confronted by fuel prices-for instance through household energy bills or at the gasoline station - makes it easy for them to trace the price mark-up back to tax rises. In contrast, non-market measures either do not spark nearly the same level of attention or limits translate into price changes only with a lag. Thus, using non-market-based measures — which overall are still efficient ways to reduce carbon emissions (IMF, 2019)—seem to stand a reasonable chance of escaping political blame (Weaver, 1986; Pierson, 1994) and thus of overcoming the political cost of CCPs.

An exception is the EPS on diesel. While diesel tax changes do not have a significant effect on popular support (Table 4), nonmarket-based measures on diesel do (Table 5). This 
could be because such measures are visible inasmuch as they prevent diesel vehicles from entering inner-city areas. A price mark-up on diesel could be less politically costly owing to lower price elasticity for this fuel relative to others (Dahl, 2012; Winebrake et al., 2015).

\section{Mediating factors}

What factors might mediate political costs? In this section, we test four key channels that have widely been discussed in the literature. First, global energy prices (FRED, 2020a; FRED, 2020b) might play an essential role in how citizens perceive stricter climate change legislation. This is because environmental policy measures create economic costs through price or quantity changes which voters have to absorb. Second, because CCPs impact especially emission-intensive sectors (Fankhaeser et al., 2008), we would expect that countries with a large input share of dirty-energy would face higher political obstacles than others. Here, we proxy industrial vulnerability to CCPs by the value-added share of dirty-energy mining industries (OECD, 2018). Third, we look at whether CCPs are politically costly particularly at times of high income inequality, using the Gini and income share data as measures (OECD, 2017; WID, 2020). Fourth, we examine whether social insurance to the losers from CCP tightening helps mitigate political costs, proxying such compensation by the generosity of the social protection system measured as social expenditure relative to GDP (Adema et al., 2011). Our specification for examining these channels is:

$y_{i, t}=F\left(z_{i, t}\right) *\left[\beta^{L} \Delta E P S_{i, t}+\theta^{L} X_{i, t}\right]+\left(1-F\left(z_{i, t}\right)\right) *\left[\beta^{H} \Delta E P S_{i, t}+\theta^{H} X_{i, t}\right]+\alpha_{i}+\gamma_{t}+$ $\epsilon_{i, t}$

with $F\left(z_{i, t}\right)=\frac{e^{-1.5 * z_{i, t}}}{1+e^{-1.5 * z_{i, t}}}$

where $\mathrm{z}$ is the $\mathrm{z}$-score (normalized to have zero mean and unit variance) of the following variables $(M)$ : (i) oil and gas price; (ii) value added share of dirty-energy mining industries (mining and oil); (iii) income shares and inequality measures; and (iv) social expenditure in 
percent of GDP. $z_{i, t}=\left(\frac{\bar{M}_{i t}-\overline{M_{l}}}{\sigma_{M i}}\right) \cdot{ }^{9} F\left(z_{i t}\right)$ is the smooth transition function of the variable $z$. The coefficients $\beta^{L}$ and $\beta^{H}$ capture the impact of changes in EPS in cases of low $M\left(F\left(z_{i t}\right) \approx 1\right.$ when $z$ goes to minus infinity) and high $M\left(\left(1-F\left(z_{i t}\right) \approx 1\right.\right.$ when z goes to plus infinity), respectively. ${ }^{10}$

The use of the smooth transition function is equivalent to the smooth transition autoregressive (STAR) model developed by Granger and Teravirta (1993) to assess non -linear effects above/below a given threshold or regime. The main advantage of this approach relative to estimating SVARs for each regime is that it uses a larger number of observations to compute the effects, improving the stability and precision of the estimates. In addition, this estimation strategy can also handle the potential correlation of the standard errors within countries more easily by clustering at the country level.

Starting with the results for fuel prices, we find that the effect of CCPs on governmental support depends on gasoline and oil market conditions, consistent with both sources of energy being the main sources of household energy consumption in OECD countries (Eurostat, 2017). In times of high oil and gasoline prices, the political damage from CCPs is statistically significantly negative - with coefficients 1.5 to 2 times as large as the direct effect in our baseline (Table 6, column 1-2). In contrast, the effect is not statistically different from zero when EPS rises in times of low global fuel prices. This implies that timing plays a substantial role from a political standpoint: governments can mitigate the political costs to a large extend by passing new legislation when fuel market conditions are favorable. This said, our estimation strategy only allows us to draw conclusions about fuel prices in the year of CCP implementation. Thus, it could be that governments are penalized in subsequent years should fuel prices rise again.

Overall, we interpret these results in two ways. First, adopting new measures when fuel prices are low gives an offsetting effect from more stringent environmental regulation on domestic budget constraints. In such cases, CCPs may fly under the political radar. Second, there

\footnotetext{
${ }^{9}$ Thus, we look at within-country varia tion over time. Since the importance of the dirty energy mining industry and the initial levels of EPS is influenced by CCPs, we a ddress this endogeneity issue by looking at cross-country variation-defining $z_{i, t}=\left(\frac{{ }_{i_{f i r s t}}-\bar{M}}{\sigma_{M}}\right)$. In other words, we use the first value that is a vaila ble in our da taset.

${ }^{10} F\left(z_{i t}\right)=0.5$ is the cut-off between the weak and strong regimes. The approach is similar to considering a dummy variable that takes value 1 when the variable is about the country-specific mean - that is, $F\left(z_{i t}\right)>=0.5$, and zero otherwise. The difference is that instead of considering two discrete values ( 0 and 1$)$, the smooth transition approaches a llow the regimes to continuously vary between 0 and 1 .
} 
is a well-established literature on an inverted $\mathrm{U}$-shaped relation between incomes and support for CCPs - a kind of environmental Kuznets curve (Dinda, 2004): environmental damage increases initially with rising levels of income per capita, but then diminishes. There is also micro evidence that support for CCPs rises with incomes, and so a greater willingness-to-pay for green policies (Carlsson and Johansson-Stenman, 2000; Franzen, 2003; Kotchen et al., 2013; see Torgler et al., 2007). So, it is plausible that relaxing budget constraints through real income gains in times of low fuel prices could increase support for CCPs among voters.

CCPs have differential effects across sectors. This is because environmental policy legislation adversely affects dirty-energy-producing industries more than other sectors (IMF, 2019). Our results show that in countries with a large share of dirty-energy sectors such as Norway and Indonesia, more stringent CCPs garner larger political costs (Table 6, column 3). The effect is not significant for countries where dirty-energy sectors have a very low weight in national input shares such as in Slovenia and Ireland. Employees in dirty-energy sectors will be adversely affected by more stringent EPS and would tend to oppose such policies owing to risks of worker displacement and lost wages. While CCPs would also create new employment opportunities, transition costs could be substantial, and matching skills in declining sectors to new job opportunities difficult. A labor force with lower educational levels, higher age structure and extensive skill-specificity could be difficult to re-allocate to new positions in clean-energy sectors. In addition, we have also tested whether left-wing parties - which have historically a strong commitment to industrial workers (Kono, 2020) - face greater political costs when adopting stricter CCP. Our results provide evidence for this hypothesis (Table A5). Finally, while we cannot draw conclusions about the lobbying power of such industries, it is possible that interest groups favoring emission-intensive sectors could substantially constrain environmentalfriendly governments (Jenkins, 2014; Cadoret and Padovano, 2016). In addition to the industrial composition, we also find that the political costs of $\mathrm{CCP}$ are higher in countries which started from stricter levels of environmental legislation in the early 2000s. This finding points towards potential non-linear effects in the cost function in a cross-sectional perspective: voters from environmental-friendly countries may penalize the government for stricter CCP when they feel that their economy is losing out against others which do not undertake CCPs.

The political costs of CCPs are larger when changes in EPS are implemented when income inequality is high - measured through market- and net-based Gini coefficients (Table 7). 
But the effects are not statistically different from zero when changes in EPS are adopted in times of low inequality. Likewise, when CCPs are implemented in times of high top-income shares, the political damage is statistically significant (Table 7). The effect disappears when top income shares is low. This pattern also holds for bottom income shares, i.e., when these are low, the political cost of CCPs is evident, but not vice-versa. A slight wrinkle is that the bottom 1 percent-income share does not affect political cost, consistent with the limited political representation and participation of the very poor (Lijphart, 1997).

All these results point to the conclusion that the level of inequality at times of stricter environmental policy adoption matter for the size of the political costs. One reason why inequality is an important driver of the political cost of EPS is that CCPs impact prices of basic goods which by their nature are not easily substitutable and have a low-price elasticity of demand (Eitches and Crain, 2016). This means that while all households are affected by CCPs, a price jump for energy products hits households at the lower end of the income distribution more than the upper income deciles (Rao, 2013); there are implications for preferences for more stringent EPS across income levels (Carlsson and Johansson-Stenman, 2000; Franzen, 2003; Kotchen et al., 2013; see Torgler et al., 2007).

In order to test whether direct compensation can reduce political costs, we examine the role of social expenditure (Table 7). We find that lower social expenditure makes EPS rises particular damaging politically, but that the coefficient on the interaction term loses significance when generous social expenditure compensates for the financial costs from CCPs. Our results show that unemployment benefits and active labor market policies are particularly effective tools in this respect, as are to some extent other components of social spending (except social expenditure on housing-see Table A3).

Although we have tested further transmission channels, they do not turn out to mediate the effect of CCPs on popular support. With respect to aggregate economic performance, we do not find a significant difference between low and high growth periods. Using the difference between market and net-based Gini coefficient as a measure for redistribution, we do not find an effect on political cost. Finally, neither the vote share of green parties, fractionalization of the opposition, nor the democratic accountability measure seem to drive the variation in political costs. 


\section{INSTRUMENTAL VARIABLE ESTIMATION}

Three considerations drive us to move beyond OLS estimation. The first is o mitted variable bias (OVB). While our model accounts for unobserved cross-country and -period heterogeneity and controls for numerous determinants of government support in line with the political economy literature, we cannot exclude the possibility of OVB. A second issue is reverse causality, where the bias can actually go in either direction. On the one hand, governments might require political capital—proxied by popular support — to implement reforms. This selection bias implies a positive effect of the dependent variable on our policy variable and biases the OLS estimate towards zero. On the other hand, a government might implement CCPs because its unpopularity implies it has little to lose from implementing reforms. This would imply a negative effect of popular support on CCPs and thus the possibility that the OLS estimate could overestimate the true effect. Third, we cannot exclude measurement error, especially when using policy reform indicators. ${ }^{11}$ If the measurement error is uncorrelated with the error term, we lose precision, but if there is correlation, attenuation bias leads to distorted coefficient estimates.

\section{A. IV Estimation of the Baseline Model}

Following Nunn and Quian (2014), out IV approach consists of interacting a time-varying global term and a constant country-specific term. The global term we consider approximates the "policy pressure" that climate change induces at the supra-national level. Here, we use indicators on the occurrence and consequences of extreme weather events in a given year. In particular, we look at the number of flood events, the number of major hurricanes in the North Atlantic, the number of people affected by earthquakes and the number of wildfires around the globe per annum. This choice of instrument is consistent with previous evidence that preferences toward CCPs changes after major natural disasters (Bird et al., 2014; Welsch and Biermann, 2014; Latré et al., 2017), with such changes in policy toward more sustainability (Meyer and Schoen, 2017). In addition,

\footnotetext{
${ }^{11}$ There are numerous challenges in the measurement of reform indicators (Clinton, 2017. Reducing the dimensionality of legisla tion to a few numerical in dicators is one issue (Benoit and Laver, 2012). Second, the scoring cla ssification is ultimately based on arbitrary ex-ante defined schemes, and the integer-based nature of the indica tors reduces substantial variation in the policy levels. In our context, the EPS indicators provide only an ordinal ranking and it is merely a ssumed that the ga ps between the different levels are equal in size; the size of the mea surement uncertainty is a lso unknown given the la ck of standard errors a round the estimates.
} 
it is reasonable to assume that such global weather events are exogenous and do not drive popular support in a single country.

The country term we consider captures the vulnerability towards climate change which makes the adoption of CCPs more likely. For this purpose, geographical characteristics seem suitable measures since they can reasonably be assumed to be randomly distributed across countries and thus should not drive government support. We consider country-specific measures such as the length of the coastline, the minimum distance of a country's centroid to the coast, the share of urban population in coastal area, and agricultural land (in $\mathrm{km}^{2}$ ) per capita.

The theoretical rationale for our pressure-vulnerability instrument is based on the "war of attrition" model proposed by Alesina and Drazen (1991). According to this model, reforms to correct unstainable long-term trends (such as persistent increases in debt or in emissions in our case) are often delayed when they have distributional implications. Reforms occur only when a given group concedes and is "forced" to bear the adjustment. In this model, a cris is (natural disaster) may induce reform "because the relative cost of fighting the war tilts in favor of concession" (Alesina et al., 2006, p.5). Overall, we have constructed five instruments consisting of interactions between a time-varying global term and a constant country term. ${ }^{12}$ Our IV estimation reads as follows:

$$
y_{i, t}=\beta \Delta \widehat{E P S}_{l, t}+\theta X_{i, t}+\alpha_{i}+\gamma_{t}+\epsilon_{i, t}
$$

with

$$
\Delta \widehat{E P S}_{l, t}=\vartheta S_{i, t}+\varphi X_{i, t}+\alpha_{i}+\gamma_{t}+v_{i, t}
$$

where $S$ is the instrument. The analysis also controls for country and time fixed effects and can therefore be seen as a differences-in-differences approach. As the baseline instrument, we use the interaction between the number of floods in the world per annum and a country's coastline length - this instrument exhibited the strongest F-test in the first stage regressions. For all five instruments, the first stage estimates suggest that the instrument is "strong" and statistically

\footnotetext{
${ }^{12}$ The instruments a re the interaction between: (i) the global number of flood events and the length of a country's coastline (WRI); (ii) the global number of flood events a nd the length of a country's coastline(FB); (iii) the frequency of major hurricanes in the North Atlantic and distance from the centroid of a country to the nearest co ast; (iv) the global number of people affected by earthquakes and the (log) sha re of urban extent in coa stal zone affected by sea level elevation; and (v) the global number of wildfires and a country's agricultural land per capita.
} 
significant. The Kleibergen-Paap rk Wald F statistic — which is equivalent to the F-effective statistic for non-homoskedastic error in case of one endogenous variable and one instrument (Andrews et al., 2019)—is higher than the associated Stock-Yogo critical value.

Our IV results support the findings obtained with OLS (Table 8): the baseline IV result indicates a significant negative effect of EPS changes for all five instruments with similar-sized coefficients. However, the magnitude of the IV coefficient estimates is approximately three times larger than the OLS estimate, which suggests that OLS estimates are biased towards zero. This is an informative outcome given that the direction of bias was ambiguous ex ante. We also test the effect of EPS changes with the vote share of the incumbent on the left-hand-side. Although only one out of five instruments is sufficiently strong to draw conclusions, the IV results of this model are in line with the popular support estimation (Table A4).

To test the validity of our instruments, we run several checks. First, we test whether the instruments have a direct effect on popular support by including them stepwise as additional controls in the baseline model (Table 3 column 1). If the coefficients turn out to be significant, one can argue that the instruments are part of the error term and thus do not satisfy the exclusion restriction. As the results in Table 9 show, this is not the case, since all five instruments turn out to be insignificant. Second, instead of regressing popular support on the instruments, we also test directly the association of the baseline residuals and the instrument. Again, the relationship is indistinguishable from zero (Table 10), which supports the valid ity of our instruments.

Third, it might well be that our global term is associated with other global factors that affect political support. For instance, climate change pressure might be associated with global trends in political conflict or aversion towards globalization. These factors could affect popular support via country-specific factors spuriously related to countries' vulnerability to climate change. To test for this concern, we augment the baseline IV specification by including the interaction between length of the coastline with global factors such as: the overall globalization index from the KOF dataset (see Gygli et al., 2019), which captures an aggregate of economic, social and political dimensions of globalization; the global average of the weighted conflict index from the ICRG dataset; and the global average of the riot index from the ICRG dataset (Table 11 columns I-III).

Another concern is that our country's specific term is associated with country characteristics (such as country size) that may affect political support through factors spuriously 
related to global pressure for climate change (such as globalization). For example, globalization may be more relevant for smaller countries and the popular support for globalization policies for smaller economies may be different than for larger economies. To address this concern, we further control for the interaction between the number of flood events and country size and the interaction the global globalization index and country size. The results are similar to, and not statistically different from, the baseline IV results (Table 11 column IV and V, respectively).

\section{B. IV Estimation of the Interaction Models}

We now extend the IV estimation to include the mediating factors described previously. The setup is similar to the regime-dependent IV approach of Ramey and Zubairy (2018):

$$
\begin{gathered}
y_{i, t}=\beta \Delta{\widehat{E P S^{D}}}_{l, t}+\theta X_{i, t}+\alpha_{i}+\gamma_{t}+\epsilon_{i, t} \\
\text { with } \Delta{\widehat{E P S^{D}}}_{l, t}=\vartheta\left[F^{D}(Z) * S_{i, t}\right]+\varphi X_{i, t}+\alpha_{i}+\gamma_{t}+v_{i, t}
\end{gathered}
$$

while $D \in\{H, L\}$.

The IV results in the extended model support our previous OLS estimates (Table 12). Adopting CCPs in times of high oil and gas prices raises the political costs (Table 12-1). Likewise, a higher dirty-energy input share raises political costs, which are three times as large as in countries with low dirty energy input shares (Table 12-2). We also find backing for the level effects in the IV estimations: the political costs of CCPs are higher in countries which had already higher levels of environmental protection in the early 2000s. In contrast, we do not find significant coefficients for low oil and gas prices as well as EPS levels, the respective instruments in these models are too weak to draw further conclusions.

The OLS results also hold for the mediating effects of inequality: CCPs in times of high (low) top (bottom) income shares lead to significantly larger political costs (Table 12-3 and Table 12-4). The results for the Gini are in line with this conclusion (Table 12-5), and the instruments are sufficiently strong. Finally, the findings on the mediating ef fect of social expenditure are also in line with the baseline estimates (Table 12-6): for each of the social 
expenditure components (overall, ALMP-related and unemployment benefits), the conclusion is that CCPs are not politically costly when generous social benefits counteract regressivity of stricter environmental legislation.

\section{Policy IMPlications AND CONCLUSIONS}

While our results confirm that CCPs on average may undercut the popularity of governments on average, we show that there are effective mitigating strategies that limit or even remove the detrimental political consequences.

First, the type of CCP matters. While market-based measures (i.e. emission taxes) lower government popularity substantially, the political cost is not significant for nonmarket-based instruments (e.g., emission limits). Since economists consider market-based instruments to be the most efficient, it is important to internalize when rendering policy advice that such measures might also be relatively costly politically. Since non-market-based measures remain viable instruments to reduce carbon emissions (IMF, 2019), such secondbest options from an economic efficiency standpoint should be on the table, lest the perfect become the enemy of the good (Pearce, 2005; Stiglitz, 2019).

$\underline{\text { Second }}$ timing matters. The consequences of tightening environmental regulation seem to be more visible when the changes adjust energy prices - especially energy and fuel prices for households. Thus, adopting CCPs when world energy prices are low can provide an effective avenue for overcoming political-economy challenges. There is a message for exploiting today's environment of very low world prices in an opportunistic fashion to move ahead with greener policies.

Third, inequality matters for the feasibility of CCPs. The economic burden from CCPs seem likely to be concentrated among certain groups, and especially those with weaker initial conditions and less resilience. Our results show that when CCPs are adopted in times of high inequality, political costs are magnified. Redistributive instruments targeted at the losers, and trampoline policies to allow workers to more easily migrate from losing sectors to growing ones, are a tried and, in our view based on the data, true recipe for overcoming the political fallout from CCPs.

CCPs will be more of a challenge when economies are more reliant on dirty industries (like mining) since the labor force in such sectors is likely to face extensive job risks. Since 
these employees may not be easily able to migrate to job opportunities in emerging sectors, permanent unemployment is a concern. Thus, governments where these dirty sectors loom large are likely to be punished at the ballot box. In order to reduce such political costs, policies to enhance sectoral and regional diversification ex-ante are likely to pay dividends. Climate change will be on the global policy agenda for years to come. As with all policies that generate winners and losers, CCPs require political support to be viable. Rational governments will continue to hesitate and delay because the political damage is palpable. Overcoming this bad equilibrium of inaction is urgent. Our hope is that the evidence and strategies identified in this paper may provide some guidance on ways forward. 


\section{REFERENCES}

Adams, J., Clark, M., Ezrow, L. and Glasgow, G., 2006. Are niche parties fundamentally different from mainstream parties? The causes and the electoral consequences of Western European parties' policy shifts, 1976-1998. American Journal of Political Science, 50(3), pp.513-529.

Adema, W., Fron, P. and Ladaique, M., 2011. Is the European welfare state really more expensive?.

Akerlof, G., Aumann, R., Deaton, A., Diamond, P., Engle, R., Fama, E., ... \& Kahneman, D. (2019). Economists' statement on carbon dividends. Wall Street Journal, A13.

Aldy, J. E., Barrett, S., \& Stavins, R. N. (2003). Thirteen plus one: a comparison of global climate policy architectures. Climate policy, 3(4), 373-397.

Alesina, A. and Drazen, A., 1991." Why Are Stabilizations Delayed?". American Economic Review, 81(11), pp.70-88.

Alesina, A., Ardagna, S. and Trebbi, F., 2006. Who adjusts and when? The political economy of reforms. IMF Staff Papers, 53(1), pp.1-29.

Alesina, A.F., Furceri, D., Ostry, J.D., Papageorgiou, C. and Quinn, D.P., 2020 a. Structural Reforms and Elections: Evidence from a World-Wide New Dataset (No. w26720). National Bureau of Economic Research.

Alesina, Alberto, Gabriele Ciminelli, Davide Furceri, and Giorgio Saponaro. 2020b. "Austerity and Elections." IMF Working Papers (forthcoming), International Monetary Fund, Washington, DC.

Beiser-McGrath, L. F., \& Bernauer, T. (2019). Could revenue recycling make effective carbon taxation politically feasible?. Science advances, 5(9), eaax3323.

Benoit, K. and Laver, M., 2012. The dimensionality of political space: Epistemological and methodological considerations. European Union Politics, 13(2), pp.194-218.

Benoit, K., Laver, M. and Mikhaylov, S., 2009. Treating words as data with error: Uncertainty in text statements of policy positions. American Journal of Political Science, 53(2), pp.495-513.

Bird, D.K., Haynes, K., van den Honert, R., McAneney, J. and Poortinga, W., 2014. Nuclear power in Australia: A comparative analysis of public opinion regarding climate change and the Fukushima disaster. Energy Policy, 65, pp.644-653.

Botta, E. and Koźluk, T., 2014. Measuring environmental policy stringency in OECD countries.

Brunel, C. and Levinson, A., 2013. Measuring environmental regulatory stringency.

Burke, M., Hsiang, S.M. and Miguel, E., 2015. Global non-linear effect of temperature on economic production. Nature, 527(7577), pp.235-239.

Cadoret, I. and Padovano, F., 2016. The political drivers of renewable energies policies. Energy Economics, 56, pp.261-269.

Carattini, S., Carvalho, M. and Fankhauser, S., 2018. Overcoming public resistance to carbon taxes. Wiley Interdisciplinary Reviews: Climate Change, 9(5), p.e531. 
Carl, J., \& Fedor, D. (2016). Tracking global carbon revenues: A survey of carbon taxes versus cap-and-trade in the real world. Energy Policy, 96, 50-77.

Carlsson, F. and Johansson-Stenman, O., 2000. Willingness to pay for improved air quality in Sweden. Applied Economics, 32(6), pp.661-669.

Center for Global Development., 2015. Developed Countries Are Responsible for 79 Percent of Historical Carbon Emissions. Retrieved September 01, 2020, from https://www.cgdev.org/media/who-caused-climate-change-historically

Center for International Earth Science and Information Network (CIESIN)/Columbia University. 2013. Sea Level Rise Impacts on Ramsar Wetlands of International Importance. Palisades, NY: NASA Socioeconomic Data and Applications Center (SEDAC). http://sedac.ciesin.columbia.edu/data/set/lecz-slr-impacts-ramsar-wetlands

Clinton, J.D., 2017. Coding the Ideological Direction and Content of Policies. Annual Review of Political Science, 20, pp.433-450.

Cruz, C., Keefer, P., and Scartascini, C., 2016. Database of Political Institutions 2015: Codebook. Washington, DC: Inter-American Development Bank. Database of Political Institutions 2017 Codebook

Dahl, C.A., 2012. Measuring global gasoline and diesel price and income elasticities. Energy Policy, 41, pp.2-13.

De Vries, C.E. and Giger, N., 2014. Holding governments accountable? Individual heterogeneity in performance voting. European Journal of Political Research, 53(2), pp.345-362.

Dell, M., Jones, B.F. and Olken, B.A., 2012. Temperature shocks and economic growth: Evidence from the last half century. American Economic Journal: Macroeconomics, 4(3), pp.66-95.

Diffenbaugh, N.S. and Burke, M., 2019. Global warming has increased global economic inequality. Proceedings of the National Academy of Sciences, 116(20), pp.98089813.

Dinda, S., 2004. Environmental Kuznets curve hypothesis: a survey. Ecological economics, 49(4), pp.431-455.

Dolezal, M., 2010. Exploring the stabilization of a political force: The social and attitudinal basis of green parties in the age of globalization. West European Politics, 33(3), pp.534-552.

Drazen, A. and Grilli, V., 1993. The benefit of crisis for reform. American Economic Review, pp.588-608.

Eckstein, D., Künzel, V., Schäfer, L. and Winges, M., 2019. Global climate risk index 2020. Germanwatch Available at: https://germanwatch. org/sites/germanwatch. org/files/202-01 e\% 20Global, 20.

Eitches, E. and Crain, V., 2016. Using gasoline data to explain inelasticity.

EMDAT (2020): OFDA/CRED International Disaster Database, Université catholique de Louvain - Brussels - Belgium 
Eurostat., 2017. Energy consumption and use by households. Retrieved September 01, 2020, from https://ec.europa.eu/eurostat/web/products-eurostat-news/-/DDN-20170328-1

Ezrow, L., De Vries, C., Steenbergen, M. and Edwards, E., 2011. Mean voter representation and partisan constituency representation: Do parties respond to the mean voter position or to their supporters?. Party Politics, 17(3), pp.275-301.

Factbook, 2020. Washington, DC: Central Intelligence Agency, 2020.

Fankhaeser, S., Sehlleier, F., \& Stern, N. (2008). Climate change, innovation and jobs. Climate policy, 8(4), 421-429.

Federal Reserve Bank of St. Louis and US, 2020a. Global Price for Brent Crude [POILBREUSDA], Retrieved September 01, 2020, from https://fred.stlouisfed.org/series/POILBREUSDA

Federal Reserve Bank of St. Louis and US, 2020b. Global price of Natural Gas, US Henry Hub Gas [PNGASUSUSDA], Retrieved September 01, 2020, from https://fred.stlouisfed.org/series/PNGASUSUSDA

Fernandez, C., Ley, E., \& Steel, M. F. (2001). Model uncertainty in cross-country growth regressions. Journal of Applied Econometrics, 16(5), 563-576.

Fernandez, R. and Rodrik, D., 1991. Resistance to reform: Status quo bias in the presence of individual-specific uncertainty. The American economic review, pp.1 146-1155.

Franzen, A., 2003. Environmental attitudes in international comparison: An analysis of the ISSP surveys 1993 and 2000. Social science quarterly, 84(2), pp.297-308.

Goulder, L.H. and Parry, I.W., 2008. Instrument choice in environmental policy. Review of environmental economics and policy, 2(2), pp.152-174.

Goulder, L.H., Hafstead, M.A., Kim, G. and Long, X., 2019. Impacts of a carbon tax across US household income groups: What are the equity-efficiency trade-offs? Journal of Public Economics, 175, pp.44-64.

Granger, Clive W. J., and Timo Teräsvirta. 1993. Modelling Nonlinear Economic Relationships. New York: Oxford University Press.

Green-Pedersen, C. and Mortensen, P.B., 2010. Who sets the agenda and who responds to it in the Danish parliament? A new model of issue competition and agenda-setting. European Journal of Political Research, 49(2), pp.257-281.

Guivarch, C., Crassous, R., Sassi, O. and Hallegatte, S., 2011. The costs of climate policies in a second-best world with labour market imperfections. Climate Policy, 11(1), pp.768-788.

Gygli, S., Haelg, F., Potrafke, N. and Sturm, J.E., 2019. The KOF globalisation indexrevisited. The Review of International Organizations, 14(3), pp.543-574.

Habla, W. and Roeder, K., 2017. The political economy of mitigation and adaptation. European Economic Review, 92, pp.239-257.

Hammar, H. and Jagers, S.C., 2006. Can trust in politicians explain individuals' support for climate policy? The case of CO2 tax. Climate Policy, 5(6), pp.613-625. 
Herrnstadt, E. and Muehlegger, E., 2014. Weather, salience of climate change and congressional voting. Journal of Environmental Economics and Management, 68(3), pp.435-448.

Hsiang, S., Kopp, R., Jina, A., Rising, J., Delgado, M., Mohan, S., Rasmussen, D.J., MuirWood, R., Wilson, P., Oppenheimer, M. and Larsen, K., 2017. Estimating economic damage from climate change in the United States. Science, 356(6345), pp.1362-1369.

Hsiang, S.M. and Burke, M., 2014. Climate, conflict, and social stability: what does the evidence say?. Climatic Change, 123(1), pp.39-55.

ICRG, 2020, "International Country Risk Guide (ICRG) Researchers Dataset"

IMF. 2019. Fiscal Monitor: How to Mitigate Climate Change. Washington, October.

IMF. 2020. World Economic Outlook: Growth and Distribution Friendly Climate Chan ge Mitigation Strategies. Washington, DC, October.

Jenkins, J.D., 2014. Political economy constraints on carbon pricing policies: What are the implications for economic efficiency, environmental efficacy, and climate policy design?. Energy Policy, 69, pp.467-477.

Kahn, M. E., Mohaddes, K., Ng, R. N., Pesaran, M. H., Raissi, M., \& Yang, J. C. (2019). Long-term macroeconomic effects of climate change: A cross-country analysis (No. w26167). National Bureau of Economic Research.

Klenert, D., Mattauch, L., Combet, E., Edenhofer, O., Hepburn, C., Rafaty, R. and Stern, N., 2018a. Making carbon pricing work for citizens. Nature Climate Change, 8(8), pp.669-677.

Klenert, D., Schwerhoff, G., Edenhofer, O. and Mattauch, L., 2018b. Environmental taxation, inequality and Engel's law: The double dividend of redistribution. Environmental and Resource Economics, 71(3), pp.605-624.

Koch, N. and Mama, H.B., 2019. Does the EU Emissions Trading System induce investment leakage? Evidence from German multinational firms. Energy Economics, 81, pp.479492.

Kono, D.Y., 2020. Compensating for the climate: unemployment insurance and climate change votes. Political Studies, 68(1), pp.167-186.

Kotchen, M.J., Boyle, K.J. and Leiserowitz, A.A., 2013. Willingness-to-pay and policyinstrument choice for climate-change policy in the United States. Energy Policy, 55, pp.617-625.

Latré, E., Perko, T. and Thijssen, P., 2017. Public opinion change after the Fukushima nuclear accident: the role of national context revisited. Energy Policy, 104,pp.124133.

Laver, M., Benoit, K. and Garry, J., 2003. Extracting policy positions from political texts using words as data. American political science review, 97(2), pp.311-331.

Li, A., \& Lin, B. (2013). Comparing climate policies to reduce carbon emissions in China. Energy Policy, 60, 667-674. 
Lijphart, A., 1997. Unequal participation: Democracy's unresolved dilemma presidential address, American Political Science Association, 1996. American political science review, 91(1), pp.1-14.

Liu, X., Lindquist, E. and Vedlitz, A., 2011. Explaining media and congressional attention to global climate change, 1969-2005: An empirical test of agenda-setting theory. Political Research Quarterly, 64(2), pp.405-419.

Magnus, J. R., Powell, O., \& Prüfer, P. (2010). A comparison of two model averaging techniques with an application to growth empirics. Journal of Econometrics, 154(2), 139-153.

Markkanen, S., \& Anger-Kraavi, A. (2019). Social impacts of climate change mitigation policies and their implications for inequality. Climate Policy, 19(7), 827-844.

McKibbin, W. J., \& Wilcoxen, P. J. (2002). The role of economics in climate change policy. Journal of economic perspectives, 16(2), 107-129.

Meguid, B.M., 2005. Competition between unequals: The role of mainstream party strategy in niche party success. American Political Science Review, pp.347-359.

Metcalf, G.E., 2009. Designing a carbon tax to reduce US greenhouse gas emissions. Review of Environmental Economics and Policy, 3(1), pp.63-83.

Meyer, M. and Schoen, H., 2017. Avoiding vote loss by changing policy positions: The Fukushima disaster, party responses, and the German electorate. Party Politics, 23(4), pp.424-436.

Muntean, M., Guizzardi, D., Schaaf, E., Crippa, M., Solazzo, E., Olivier, J., \& Vignati, E. (2018). Fossil CO2 emissions of all world countries. Luxembourg: Publications Office of the European Union.

Nakamura, E. and Steinsson, J., 2018. Identification in macroeconomics. Journal of Economic Perspectives, 32(3), pp.59-86.

Nationmaster. 2007. Countries Compared by Agriculture Agricultural land Sq. km Per capita. International Statistics. Retrieved October 15, 2020, from https://www.nationmaster.com/country-info/stats/Agriculture/Agricultural-land/Sq.$\mathrm{km} /$ Per-capita

NOAA. (2019). HURDAT comparison table. Retrieved October 15, 2020, from https://www.aoml.noaa.gov/hrd/hurdat/comparison table.html

Nunn, N. and Qian, N., 2014. US food aid and civil conflict. American Economic Review, 104(6), pp.1630-66.

OECD, 2012. The Jobs Potential of a Shift Towards a Low-Carbon Economy. OECD Publishing.

OECD, 2017. OECD income distribution database (IDD): Gini, poverty, income, methods and concepts. Social and welfare issues.

OECD, 2018. Input-Output Tables. For download at http://oe.cd/i-o. Organisation for Economic Co-operation and Development, Paris

Ostry, J.D., A. Berg and S. Kothari. 2020. "Growth Equity Trade-offs in Structural Reforms." Scottish Journal of Political Economy, forthcoming. 
Ostry, J.D., P. Loungani and A. Berg, 2019. Confronting Inequality: How Societies Can Choose Inclusive Growth. Columbia University Press.

Persson, T. and Tabellini, G., 2016. Political economics. Cambridge, MA: MIT press.

Pew Research Center, 2019. Climate Change Still Seen as the Top Global Threat, but Cyberattacks a Rising Concern

Pierson, P., 1994. Dismantling the welfare state?: Reagan, Thatcher and the politics of retrenchment. Cambridge University Press.

Pierson, P., 1996. The new politics of the welfare state. World politics, 48(2), pp.143-179.

Portland State University., 2020. Country Geography Data. Retrieved August 17, 2020, from https://www.pdx.edu/econ/country-geography-data.

Ramey, V.A. and Zubairy, S., 2018. Government spending multipliers in good times and in bad: evidence from US historical data. Journal of Political Economy, 126(2), pp.850901.

Rao, N.D., 2013. Distributional impacts of climate ch ange mitigation in Indian electricity: The influence of governance. Energy policy, 61, pp.1344-1356.

Rojas-Vallejos, J. and Lastuka, A., 2020. The income inequality and carbon emissions tradeoff revisited. Energy Policy, 139, p.111302.

Samuelson, W. and Zeckhauser, R., 1988. Status quo bias in decision making. Journal of risk and uncertainty, 1(1), pp.7-59.

Sovacool, B.K., Linnér, B.O. and Goodsite, M.E., 2015. The political economy of climate adaptation. Nature Climate Change, 5(7), p.616.

Spoon, J.J., Hobolt, S.B. and De Vries, C.E., 2014. Going green: Explaining issue competition on the environment. European Journal of Political Research, 53(2), pp.363-380.

Stern, N., 2008. The economics of climate change. American Economic Review, 98(2), pp.1 37.

Steves, F. and Teytelboym, A., 2013. Political economy of climate change policy.

Stiglitz, J.E., 2019. Addressing climate change through price and non-price interventions. European Economic Review, 119, pp.594-612.

Stokes, L.C., 2016. Electoral backlash against climate policy: A natural experiment on retrospective voting and local resistance to public policy. American Journal of Political Science, 60(4), pp.958-974.

Torgler, B. and Garcia-Valiñas, M.A., 2007. The determinants of individuals' attitudes towards preventing environmental damage. Ecological economics, 63(2-3), pp.536552.

Tsebelis, G., 2002. Veto players: How political institutions work. Princeton University Press. Tvinnereim, E. and Ivarsflaten, E., 2016. Fossil fuels, employment, and support for climate policies. Energy Policy, 96, pp.364-371.

Weaver, R.K., 1986. The politics of blame avoidance. Journal of Public Policy, pp.371 -398. 
Weitzman, M. L. (1974). Prices vs. quantities. The review of ec onomic studies, 41(4), 477491.

Welsch, H. and Biermann, P., 2014. Fukushima and the preference for nuclear power in Europe: Evidence from subjective well-being data. Ecological Economics, 108, pp.171-179.

Winebrake, J.J., Green, E.H., Comer, B., Li, C., Froman, S. and Shelby, M., 2015. Fuel price elasticities in the US combination trucking sector. Transportation Research Part D: Transport and Environment, 38, pp.166-177.

World Inequality Database (WID), 2020. Retrieved September 01, 2020, from https://wid.world/

World Research Institute (WRI). 2000. Coastal and Marine Ecosystems - Marine Jurisdictions: Coastline length Units: Kilometers. Retrieved October 15, 2020, from https://web.archive.org/web/20120419075053/http://earthtrends.wri.org/text/coastalmarine/variable-61.html 
TABLE 1. VARIABLE DESCRIPTION

Variable

D_Popularsupport

D.EPS

D.EPS_MKT

D.EPS_NMKT

D.TAXES

D.taxPCA

D.TAXCO2

D.TAXDIESEL

D.TAXNOX

D.TAXSOX

D.STD

D.limitPCA

D.ELV_DIESELSO

D.ELV_NOX

D.ELV_PM

D.ELV_SOX

D.FIT

D.FIT_SOLAR

D.FIT_WIND

D.TRADESCH

D.TRADESCH_CO2

D.TRADESCH_EEF

D.TRADESCH_REC

D.RD_RE

D.RD_SUB

deficit

elderly

gdpr

unemprate

cpi

voteshare

taxrevue

finref_index

product_index

current_index
Source

ICRG

OECD

OECD

OECD

OECD

OECD

OECD

OECD

OECD

OECD

OECD

OECD

OECD

OECD

OECD

OECD

OECD

OECD

OECD

OECD

OECD

OECD

OECD

OECD

OECD

OECD

OECD

WB

WB

OECD

Alesina

WB

Alesina

Alesina

Alesina

\section{Description}

level of support for the government

Environmental Policy Stringency Index (aggregated)

(first diff)

marked-based environmental policy stringency index

(first diff)

non-marked-based environmental policy stringency index (first diff)

aggregated environmental taxation index (first diff)

PCA (first) of taxation sub-indices (first diff)

taxation on $\mathrm{CO} 2$ index (first diff)

taxation on Diesel index (first diff)

taxation on NOx index (first diff)

taxation on SOx index (first diff)

aggregated limits index (first diff)

first principale component of all limits sub-indices (first

diff)

emission limits on Diesel index (first diff)

emission limits on NOx index (first diff)

emission limits on PM index (first diff)

emission limits on SOx index (first diff)

aggregated feed-in-tariffs index (first diff)

feed-in-tariffs for solar index (first diff)

feed-in-tariffs for wind index (first diff)

aggregated trading scheme index (first diff)

trading scheme for $\mathrm{CO} 2$ index (first diff)

trading scheme for Energy Efficiency Certificate index

(first diff)

trading scheme for Renewable Energy Certificate index

(first diff)

$R \& D$ subsidies for renewable energy index (first diff)

aggregated R\&D subsidies index (first diff)

general government deficit (as \% of GDP)

share of the elderly (65+) (as \% of total population)

growth rate of GDP at market prices (LCU)

unemployment, total (\% of total labour force)

consumer price index

vote share of the main governing party (or coalition)

tax revenue \% GDP

domestic financial liberalization indicator

product market liberalization indicator

current account reform indicator 


\begin{tabular}{|c|c|c|}
\hline capital_index & Alesina & capital account reform indicator \\
\hline labor_index & Alesina & labor market liberalization indicator \\
\hline oilPrice & FRED & global price for brent crude \\
\hline gasPrice & FRED & global price of natural gas \\
\hline top1share & WID & share of pre-tax national income of top 1\% \\
\hline top10share & WID & share of pre-tax national income of top $10 \%$ \\
\hline top20share & WID & share of pre-tax national income of top $20 \%$ \\
\hline bot1share & WID & share of pre-tax national income of bottom $1 \%$ \\
\hline bot10share & WID & share of pre-tax national income of bottom $10 \%$ \\
\hline bot20share & WID & share of pre-tax national income of bottom $20 \%$ \\
\hline giniMRKT & OECD & market-based Gini coefficient \\
\hline giniNET & OECD & net Gini coefficient \\
\hline socexp & OECD & total public social expenditure as percentage of GDP \\
\hline almpExp & OECD & public social expenditure for ALPM as \% of GDP \\
\hline unempExp & OECD & $\begin{array}{l}\text { public social expenditure for unemployment as } \% \text { of } \\
\text { GDP }\end{array}$ \\
\hline famExp & OECD & public social expenditure for family as \%of GDP \\
\hline healthExp & OECD & public social expenditure for health as \% of GDP \\
\hline houseExp & OECD & public social expenditure for housing as $\%$ of GDP \\
\hline incapExp & OECD & public social expenditure for incapatity as $\%$ of GDP \\
\hline oldExp & OECD & public social expenditure for old age as \% of GDP \\
\hline energyShare & OECD & $\begin{array}{l}\text { Share of value added of dirty energy producing/mining } \\
\text { industries ("mining and extraction of energy producing } \\
\text { products" (D05T06) and "Coke and refined petroleum } \\
\text { products" (D19)) }\end{array}$ \\
\hline cenDist & PSU & distance from centroid of country to nearest coast $(\mathrm{km})$ \\
\hline coastLengthWRI & WRI & length of coastline \\
\hline coastLengthFB & Factbook & length of coastline \\
\hline eventsFlood & EMDAT/OWID & number of floods (global) \\
\hline majorHurric & NOAA/OWID & frequency of major hurricanes in the North Atlantic \\
\hline peopleAffectedEQ & EMDAT/OWID & number of people affected by earthquakes (global) \\
\hline urbanCoastLOG & CIESIN & $\begin{array}{l}(\mathrm{log}) \text { share of urban extent in coastal zone }(\mathrm{km} 2) \\
\text { affected by sea level elevation }\end{array}$ \\
\hline eventsWildfire & EMDAT/OWID & number of wildfires (global) \\
\hline agriLandPC & Nationmaster & agricultural land (km2) per capita \\
\hline globalization & Gygli et al. & index of globalization (total) (global average) \\
\hline riot & ICRG & index of riot (global average) \\
\hline conflict & ICRG & index of total conflict (global average) \\
\hline logpop & WB & (log) population (in million) \\
\hline left & Cruz et al. & Dummy variable for left-wing chief of executive \\
\hline center & Cruz et al. & Dummy variable for center-wing chief of executive \\
\hline right & Cruz et al. & Dummy variable for right-wing chief of executive \\
\hline
\end{tabular}


TABLE 2. Summary Statistics

Variable
D_Popularsupport
D.EPS
D.EPS_MKT
D.EPS_NMKT
D.TAXES
D.taxPCA
D.TAXCO2
D.TAXDIESEL
D.TAXNOX
D.TAXSOX
D.STD
D.limitPCA
D.ELV_DIESELSO
D.ELV_NOX
D.ELV_PM
D.ELV_SOX
D.FIT
D.FIT_SOLAR
D.FIT_WIND
D.TRADESCH
D.TRADESCH_CO2
D.TRADESCH_EEF
D.TRADESCH_REC
D.RD_RE
D.RD_SUB
deficit
elderly
gdpr
unemprate
cpi
voteshare
taxrevue
finref_index
product_index
current_index
capital_index
labor_index
oilPrice
gasPrice
top1share

\begin{tabular}{|c|c|c|c|}
\hline Mean & Min & Max & SD \\
\hline 2.223 & 0.500 & 3.792 & 0.579 \\
\hline 0.106 & -1.400 & 1.112 & 0.317 \\
\hline 0.076 & -2.000 & 2.083 & 0.425 \\
\hline 0.136 & -2.000 & 2.000 & 0.449 \\
\hline 0.013 & -1.000 & 1.750 & 0.280 \\
\hline 0.054 & -1.006 & 2.722 & 0.335 \\
\hline 0.031 & -1.000 & 6.000 & 0.383 \\
\hline-0.071 & -4.000 & 3.000 & 0.666 \\
\hline 0.058 & -1.000 & 6.000 & 0.513 \\
\hline 0.031 & -2.000 & 6.000 & 0.413 \\
\hline 0.190 & 0.000 & 3.500 & 0.569 \\
\hline 0.200 & 0.000 & 3.689 & 0.601 \\
\hline 0.147 & 0.000 & 2.000 & 0.387 \\
\hline 0.220 & 0.000 & 5.000 & 0.906 \\
\hline 0.150 & 0.000 & 5.000 & 0.632 \\
\hline 0.242 & 0.000 & 6.000 & 0.951 \\
\hline 0.105 & -6.000 & 6.000 & 1.057 \\
\hline 0.118 & -6.000 & 6.000 & 1.168 \\
\hline 0.092 & -6.000 & 6.000 & 1.175 \\
\hline 0.104 & -2.400 & 2.800 & 0.780 \\
\hline 0.137 & -6.000 & 6.000 & 1.878 \\
\hline 0.039 & -3.000 & 4.000 & 0.317 \\
\hline 0.104 & -4.000 & 4.000 & 0.536 \\
\hline 0.082 & -4.000 & 4.000 & 0.708 \\
\hline 0.082 & -4.000 & 4.000 & 0.708 \\
\hline-2.582 & -32.063 & 18.633 & 4.613 \\
\hline 14.367 & 4.099 & 26.648 & 4.715 \\
\hline 2.230 & -9.132 & 25.163 & 2.977 \\
\hline 8.181 & 2.119 & 33.473 & 5.311 \\
\hline 0.996 & 0.476 & 2.616 & 0.227 \\
\hline-1.854 & -29.860 & 27.230 & 8.839 \\
\hline 18.946 & 7.919 & 36.500 & 6.403 \\
\hline 0.890 & 0.500 & 1.000 & 0.116 \\
\hline 0.746 & 0.182 & 1.000 & 0.183 \\
\hline 0.934 & 0.250 & 1.000 & 0.149 \\
\hline 0.897 & 0.500 & 1.000 & 0.165 \\
\hline 0.622 & 0.298 & 1.000 & 0.143 \\
\hline 68.758 & 24.412 & 111.960 & 30.665 \\
\hline 5.067 & 2.614 & 8.895 & 1.952 \\
\hline 0.117 & 0.045 & 0.296 & 0.049 \\
\hline
\end{tabular}




\begin{tabular}{|c|c|c|c|c|}
\hline top10share & 0.354 & 0.229 & 0.651 & 0.084 \\
\hline top20share & 0.500 & 0.377 & 0.792 & 0.080 \\
\hline bot1share & 0.000 & -0.006 & 0.001 & 0.001 \\
\hline bot10share & 0.010 & -0.020 & 0.027 & 0.006 \\
\hline bot20share & 0.042 & 0.012 & 0.078 & 0.014 \\
\hline giniMRKT & 47.337 & 32.917 & 69.400 & 5.679 \\
\hline giniNET & 31.890 & 22.093 & 59.400 & 7.952 \\
\hline socexp & 20.742 & 4.793 & 32.213 & 5.698 \\
\hline almpExp & 0.573 & 0.005 & 2.052 & 0.399 \\
\hline unempExp & 0.923 & 0.000 & 3.555 & 0.767 \\
\hline famExp & 2.034 & 0.134 & 3.997 & 0.949 \\
\hline healthExp & 5.728 & 2.109 & 8.869 & 1.481 \\
\hline houseExp & 0.338 & 0.000 & 1.745 & 0.347 \\
\hline incapExp & 2.229 & 0.035 & 5.540 & 1.140 \\
\hline oldExp & 8.456 & 0.853 & 17.126 & 3.509 \\
\hline energyShare & 0.027 & 0.00043 & 0.265 & 0.044 \\
\hline cenDist & 250.153 & 2.944 & 1712.840 & 377.420 \\
\hline coastLengthWRI & 28511.000 & 0.000 & 265523.000 & 53217.010 \\
\hline coastLengthFB & 16980.620 & 0.000 & 202080.000 & 39301.840 \\
\hline eventsFlood & 165.867 & 128.000 & 226.000 & 27.711 \\
\hline majorHurric & 3.200 & 0.000 & 7.000 & 1.835 \\
\hline peopleAffectedEQ & 6370539 & 786413 & 46724390 & 11012820 \\
\hline urbanCoastLOG & 0.007 & 0.000 & 0.082 & 0.017 \\
\hline eventsWildfire & 10.600 & 4.000 & 22.000 & 4.791 \\
\hline agriLandPC & 12.561 & 0.365 & 208.211 & 36.766 \\
\hline globaliz & 58.290 & 53.319 & 61.753 & 2.899 \\
\hline riot & 0.783 & 0.032 & 3.839 & 1.132 \\
\hline conflict & 834.641 & 179.419 & 2891.194 & 822.479 \\
\hline logpop & 3.268 & 0.688 & 7.152 & 1.470 \\
\hline left & 0.431 & 0 & 1 & 0.496 \\
\hline center & 0.093 & 0 & 1 & 0.29 \\
\hline right & 0.476 & 0 & 1 & 0.5 \\
\hline
\end{tabular}


TABLE 3. THE EFFECT OF EPS CHANGES ON POPULAR SUPPORT

\begin{tabular}{|c|c|c|c|c|c|c|}
\hline & (I) & (II) & (III) & (IV) & (V) & (VI) \\
\hline D.EPS & $\begin{array}{c}-0.231 * * * \\
(0.079)\end{array}$ & $\begin{array}{c}-0.246 * * * \\
(0.079)\end{array}$ & $\begin{array}{c}-0.247 * * * \\
(0.080)\end{array}$ & $\begin{array}{c}-0.266^{* * * *} \\
(0.086)\end{array}$ & $\begin{array}{c}-0.295^{* * *} \\
(0.084)\end{array}$ & $\begin{array}{c}-0.284^{* * * *} \\
(0.088)\end{array}$ \\
\hline deficit & $\begin{array}{c}0.039 * * * \\
(0.014)\end{array}$ & $\begin{array}{l}0.028^{*} \\
(0.015)\end{array}$ & $\begin{array}{l}0.027^{*} \\
(0.015)\end{array}$ & $\begin{array}{c}0.025 \\
(0.017)\end{array}$ & $\begin{array}{l}0.028^{*} \\
(0.014)\end{array}$ & $\begin{array}{c}0.029 * * \\
(0.015)\end{array}$ \\
\hline elderly & $\begin{array}{c}0.163 * * * \\
(0.051)\end{array}$ & $\begin{array}{c}0.177 * * * \\
(0.055)\end{array}$ & $\begin{array}{c}0.194 * * * \\
(0.063)\end{array}$ & $\begin{array}{c}0.172 * * \\
(0.069)\end{array}$ & $\begin{array}{c}0.196 * * * \\
(0.074)\end{array}$ & $\begin{array}{c}0.149^{* *} \\
(0.066)\end{array}$ \\
\hline gdpr & $\begin{array}{c}0.063 * * \\
(0.029)\end{array}$ & $\begin{array}{c}0.047 \\
(0.030)\end{array}$ & $\begin{array}{c}0.051 \\
(0.031)\end{array}$ & $\begin{array}{c}0.048 \\
(0.033)\end{array}$ & $\begin{array}{c}0.041 \\
(0.036)\end{array}$ & $\begin{array}{c}0.031 \\
(0.030)\end{array}$ \\
\hline unemprate & & $\begin{array}{c}-0.035^{* *} \\
(0.017)\end{array}$ & $\begin{array}{l}-0.033^{*} \\
(0.018)\end{array}$ & $\begin{array}{l}-0.028 \\
(0.022)\end{array}$ & $\begin{array}{l}-0.032 \\
(0.022)\end{array}$ & $\begin{array}{l}-0.034 \\
(0.025)\end{array}$ \\
\hline cpi & & & $\begin{array}{c}0.299 \\
(0.309)\end{array}$ & $\begin{array}{c}0.233 \\
(0.314)\end{array}$ & $\begin{array}{c}0.084 \\
(0.299)\end{array}$ & $\begin{array}{l}-0.807^{*} \\
(0.457)\end{array}$ \\
\hline voteshare & & & & $\begin{array}{l}0.010^{*} \\
(0.005)\end{array}$ & $\begin{array}{l}0.009^{*} \\
(0.005)\end{array}$ & $\begin{array}{c}0.007 \\
(0.004)\end{array}$ \\
\hline taxrevenue & & & & & $\begin{array}{l}-0.006 \\
(0.047)\end{array}$ & $\begin{array}{l}-0.007 \\
(0.045)\end{array}$ \\
\hline finref_index & & & & & & $\begin{array}{c}0.153 \\
(1.620)\end{array}$ \\
\hline product_index & & & & & & $\begin{array}{l}-0.680 \\
(0.710)\end{array}$ \\
\hline current_index & & & & & & $\begin{array}{c}1.987 \\
(1.316)\end{array}$ \\
\hline capital_index & & & & & & $\begin{array}{c}0.706 \\
(1.170)\end{array}$ \\
\hline labor_index & & & & & & $\begin{array}{c}2.260 \\
(1.998)\end{array}$ \\
\hline Constant & $\begin{array}{c}0.659 \\
(0.624)\end{array}$ & $\begin{array}{c}0.724 \\
(0.673)\end{array}$ & $\begin{array}{c}0.281 \\
(0.924)\end{array}$ & $\begin{array}{c}0.628 \\
(1.010)\end{array}$ & $\begin{array}{c}0.628 \\
(1.508)\end{array}$ & $\begin{array}{l}-1.750 \\
(1.731)\end{array}$ \\
\hline Country FE & Yes & Yes & Yes & Yes & Yes & Yes \\
\hline Time FE & Yes & Yes & Yes & Yes & Yes & Yes \\
\hline $\mathrm{R}^{2}$ & 0.455 & 0.466 & 0.468 & 0.464 & 0.493 & 0.512 \\
\hline Observations & 370 & 370 & 370 & 326 & 321 & 321 \\
\hline
\end{tabular}

Note: The outcome variable is popular support. Estimated based on $y_{i, t}=\beta \Delta E P S_{i, t}+\theta X_{i, t}+\alpha_{i}+\gamma_{t}+\epsilon_{i, t}$. A coefficient of 0.2 is equivalent to a 10 percent decline in popular support from an increase in EPS from the $1 \mathrm{st}$ to the 3 rd quartile of the EPS distribution. Standard deviations based on robust standard errors clustered at the country level in parentheses. ${ }^{* *}, * * *$ denote significance at 1,5 and 10 percent, respectively. 
TABLE 4. THE EFFECT OF MARKET-BASED EPS CHANGES ON POPULAR SUPPORT

\begin{tabular}{|c|c|c|c|c|c|c|c|}
\hline & (I) & (II) & (III) & (IV) & (V) & (VI) & (VII) \\
\hline deficit & $\begin{array}{c}0.038 * * * \\
(0.013)\end{array}$ & $\begin{array}{c}0.039 * * * \\
(0.013)\end{array}$ & $\begin{array}{c}0.040 * * * \\
(0.013)\end{array}$ & $\begin{array}{c}0.039 * * * \\
(0.013)\end{array}$ & $\begin{array}{c}0.039 * * * \\
(0.014)\end{array}$ & $\begin{array}{c}0.039 * * * \\
(0.013)\end{array}$ & $\begin{array}{c}0.039 * * * \\
(0.013)\end{array}$ \\
\hline elderly & $\begin{array}{c}0.166^{* * * *} \\
(0.053)\end{array}$ & $\begin{array}{c}0.161 * * * \\
(0.051)\end{array}$ & $\begin{array}{c}0.162 * * * \\
(0.051)\end{array}$ & $\begin{array}{c}0.151 * * * \\
(0.051)\end{array}$ & $\begin{array}{c}0.159 * * * \\
(0.052)\end{array}$ & $\begin{array}{c}0.150 * * * \\
(0.050)\end{array}$ & $\begin{array}{c}0.153 * * * \\
(0.051)\end{array}$ \\
\hline gdpr & $\begin{array}{c}0.064 * * \\
(0.028)\end{array}$ & $\begin{array}{c}0.058 * * \\
(0.027)\end{array}$ & $\begin{array}{c}0.058 * * \\
(0.027)\end{array}$ & $\begin{array}{c}0.062 * * \\
(0.027)\end{array}$ & $\begin{array}{c}0.060 * * \\
(0.027)\end{array}$ & $\begin{array}{c}0.059 * * \\
(0.027)\end{array}$ & $\begin{array}{c}0.061 * * \\
(0.027)\end{array}$ \\
\hline D.EPS_MKT & $\begin{array}{c}-0.153 * * \\
(0.074)\end{array}$ & & & & & & \\
\hline D.TAXES & & $\begin{array}{c}-0.199 * * \\
(0.092)\end{array}$ & & & & & \\
\hline D.taxPCA & & & $\begin{array}{c}-0.202 * * * \\
(0.062)\end{array}$ & & & & \\
\hline D.TAXCO2 & & & & $\begin{array}{c}-0.071 * * \\
(0.035)\end{array}$ & & & \\
\hline D.TAXDIESEL & & & & & $\begin{array}{c}0.019 \\
(0.066)\end{array}$ & & \\
\hline D.TAXNOX & & & & & & $\begin{array}{c}-0.090 * * \\
(0.042)\end{array}$ & \\
\hline D.TAXSOX & & & & & & & $\begin{array}{c}-0.196 * * * \\
(0.052)\end{array}$ \\
\hline Constant & $\begin{array}{c}0.621 \\
(0.647)\end{array}$ & $\begin{array}{c}0.684 \\
(0.628)\end{array}$ & $\begin{array}{c}0.684 \\
(0.635)\end{array}$ & $\begin{array}{c}0.785 \\
(0.619)\end{array}$ & $\begin{array}{c}0.695 \\
(0.628)\end{array}$ & $\begin{array}{c}0.839 \\
(0.611)\end{array}$ & $\begin{array}{c}0.799 \\
(0.626)\end{array}$ \\
\hline Country FE & Yes & Yes & Yes & Yes & Yes & Yes & Yes \\
\hline Time FE & Yes & Yes & Yes & Yes & Yes & Yes & Yes \\
\hline $\mathrm{R}^{2}$ & 0.452 & 0.445 & 0.450 & 0.443 & 0.439 & 0.447 & 0.450 \\
\hline Observations & 370 & 373 & 373 & 378 & 373 & 378 & 378 \\
\hline
\end{tabular}

Note: The outcome variable is popular support. Estimated based on $y_{i, t}=\beta \Delta E P S_{i, t}+\theta X_{i, t}+\alpha_{i}+\gamma_{t}+\epsilon_{i, t}$. A coefficient of -0.2 is equivalent to a 10 percent decline in popular support from an increase in EPS from the 1st to the 3rd quartile of the EPS distribution. Standard deviations based on robust s tandard errors clustered at the country level in parentheses. $* * * * *, *$ denote significance at 1,5 and 10 percent, respectively. 
Table 4 (cont). The effect of market-based EPS changes on popular support

\begin{tabular}{|c|c|c|c|c|c|c|c|}
\hline & (I) & (II) & (III) & (IV) & $(\mathrm{V})$ & (VI) & (VII) \\
\hline deficit & $\begin{array}{c}0.039 * * * \\
(0.013)\end{array}$ & $\begin{array}{c}0.039 * * * \\
(0.014)\end{array}$ & $\begin{array}{c}0.039 * * * \\
(0.013)\end{array}$ & $\begin{array}{c}0.038^{* * *} * \\
(0.013)\end{array}$ & $\begin{array}{c}0.038^{* * *} * \\
(0.013)\end{array}$ & $\begin{array}{c}0.039 * * * \\
(0.013)\end{array}$ & $\begin{array}{c}0.039 * * * \\
(0.013)\end{array}$ \\
\hline elderly & $\begin{array}{c}0.151 * * * \\
(0.051)\end{array}$ & $\begin{array}{c}0.147 * * * \\
(0.052)\end{array}$ & $\begin{array}{c}0.154 * * * \\
(0.051)\end{array}$ & $\begin{array}{c}0.159 * * * \\
(0.050)\end{array}$ & $\begin{array}{c}0.159 * * * \\
(0.051)\end{array}$ & $\begin{array}{c}0.148 * * * \\
(0.050)\end{array}$ & $\begin{array}{c}0.149 * * * \\
(0.051)\end{array}$ \\
\hline gdpr & $\begin{array}{c}0.061 * * \\
(0.027)\end{array}$ & $\begin{array}{c}0.062 * * \\
(0.027)\end{array}$ & $\begin{array}{c}0.061 * * \\
(0.027)\end{array}$ & $\begin{array}{c}0.066 * * \\
(0.028)\end{array}$ & $\begin{array}{c}0.065^{* *} \\
(0.028)\end{array}$ & $\begin{array}{c}0.062 * * \\
(0.027)\end{array}$ & $\begin{array}{c}0.061 * * \\
(0.027)\end{array}$ \\
\hline D.FIT & $\begin{array}{l}-0.028 \\
(0.022)\end{array}$ & & & & & & \\
\hline D.FIT_SOLAR & & $\begin{array}{c}-0.022 \\
(0.018)\end{array}$ & & & & & \\
\hline D.FIT_WIND & & & $\begin{array}{l}-0.024 \\
(0.020)\end{array}$ & & & & \\
\hline D.TRADESCH & & & & $\begin{array}{c}-0.084 \\
(0.060)\end{array}$ & & & \\
\hline D.TRADESCH_CO2 & & & & & $\begin{array}{c}-0.039 \\
(0.026)\end{array}$ & & \\
\hline D.TRADESCH_EEF & & & & & & $\begin{array}{c}-0.133 * * \\
(0.058)\end{array}$ & \\
\hline D.TRADESCH_REC & & & & & & & $\begin{array}{c}0.021 \\
(0.038)\end{array}$ \\
\hline Constant & $\begin{array}{c}0.807 \\
(0.619)\end{array}$ & $\begin{array}{c}0.848 \\
(0.630)\end{array}$ & $\begin{array}{c}0.765 \\
(0.620)\end{array}$ & $\begin{array}{c}0.704 \\
(0.608)\end{array}$ & $\begin{array}{c}0.684 \\
(0.613)\end{array}$ & $\begin{array}{c}0.845 \\
(0.604)\end{array}$ & $\begin{array}{c}0.812 \\
(0.619)\end{array}$ \\
\hline Country FE & Yes & Yes & Yes & Yes & Yes & Yes & Yes \\
\hline Time FE & Yes & Yes & Yes & Yes & Yes & Yes & Yes \\
\hline $\mathrm{R}^{2}$ & 0.444 & 0.443 & 0.444 & 0.455 & 0.456 & 0.446 & 0.442 \\
\hline Observations & 378 & 378 & 378 & 374 & 374 & 378 & 378 \\
\hline
\end{tabular}

Note: The outcome variable is popular support. Estimated based on $y_{i, t}=\beta \Delta E P S_{i, t}+\theta X_{i, t}+\alpha_{i}+\gamma_{t}+\epsilon_{i, t}$. A coefficient of -0.2 is equivalent to a 10 percent decline in popular support from an increase in EPS from the 1 st to the 3rd quartile of the EPS distribution. Standard deviations based on robust standard errors clustered at the country level in parentheses. $* * * * *, *$ denote significance at 1,5 and 10 percent, respectively. 
TABLE 5. THEEFFECT OF NON-MARKET-BASED EPS CHANGES ON POPULAR SUPPORT

\begin{tabular}{|c|c|c|c|c|c|c|c|c|}
\hline & (I) & (II) & (III) & (IV) & $(\mathrm{V})$ & (VI) & (VII) & (VIII) \\
\hline deficit & $\begin{array}{c}0.039 * * * \\
(0.014)\end{array}$ & $\begin{array}{c}0.039 * * * \\
(0.013)\end{array}$ & $\begin{array}{c}0.039 * * * \\
(0.013)\end{array}$ & $\begin{array}{c}0.039 * * * \\
(0.013)\end{array}$ & $\begin{array}{c}0.040^{* * *} \\
(0.013)\end{array}$ & $\begin{array}{c}0.039 * * * \\
(0.013)\end{array}$ & $\begin{array}{c}0.039 * * * \\
(0.014)\end{array}$ & $\begin{array}{c}0.039 * * * \\
(0.014)\end{array}$ \\
\hline elderly & $\begin{array}{c}0.149 * * * \\
(0.050)\end{array}$ & $\begin{array}{c}0.149 * * * \\
(0.051)\end{array}$ & $\begin{array}{c}0.145 * * * \\
(0.051)\end{array}$ & $\begin{array}{c}0.148 * * * \\
(0.052)\end{array}$ & $\begin{array}{c}0.146 * * * \\
(0.050)\end{array}$ & $\begin{array}{c}0.150 * * * \\
(0.051)\end{array}$ & $\begin{array}{c}0.148 * * * \\
(0.050)\end{array}$ & $\begin{array}{c}0.148 * * * \\
(0.050)\end{array}$ \\
\hline gdpr & $\begin{array}{c}0.061 * * \\
(0.027)\end{array}$ & $\begin{array}{c}0.061 * * \\
(0.027)\end{array}$ & $\begin{array}{c}0.057 * * \\
(0.025)\end{array}$ & $\begin{array}{c}0.061 * * \\
(0.027)\end{array}$ & $\begin{array}{c}0.061 * * \\
(0.027)\end{array}$ & $\begin{array}{c}0.062 * * \\
(0.027)\end{array}$ & $\begin{array}{c}0.062 * * \\
(0.027)\end{array}$ & $\begin{array}{r}0.062 * * \\
(0.027)\end{array}$ \\
\hline D.EPS_NMKT & $\begin{array}{l}-0.066 \\
(0.048)\end{array}$ & & & & & & & \\
\hline D.STD & & $\begin{array}{l}-0.004 \\
(0.065)\end{array}$ & & & & & & \\
\hline D.ELV_DIESELSO & & & $\begin{array}{c}-0.206 * * \\
(0.103)\end{array}$ & & & & & \\
\hline D.ELV_NOX & & & & $\begin{array}{c}0.014 \\
(0.041)\end{array}$ & & & & \\
\hline D.ELV_PM & & & & & $\begin{array}{l}-0.043 \\
(0.041)\end{array}$ & & & \\
\hline D.ELV_SOX & & & & & & $\begin{array}{c}0.020 \\
(0.037)\end{array}$ & & \\
\hline D.RD_RE & & & & & & & $\begin{array}{c}-0.050 * \\
(0.027)\end{array}$ & \\
\hline D.RD_RE & & & & & & & & $\begin{array}{l}-0.050 * \\
(0.027)\end{array}$ \\
\hline Constant & $\begin{array}{c}0.835 \\
(0.600)\end{array}$ & $\begin{array}{c}0.819 \\
(0.611)\end{array}$ & $\begin{array}{c}0.891 \\
(0.618)\end{array}$ & $\begin{array}{c}0.834 \\
(0.627)\end{array}$ & $\begin{array}{c}0.856 \\
(0.604)\end{array}$ & $\begin{array}{c}0.810 \\
(0.618)\end{array}$ & $\begin{array}{c}0.836 \\
(0.604)\end{array}$ & $\begin{array}{c}0.836 \\
(0.604)\end{array}$ \\
\hline Country FE & Yes & Yes & Yes & Yes & Yes & Yes & Yes & Yes \\
\hline Time FE & Yes & Yes & Yes & Yes & Yes & Yes & Yes & Yes \\
\hline $\mathrm{R}^{2}$ & 0.444 & 0.441 & 0.450 & 0.442 & 0.443 & 0.442 & 0.445 & 0.445 \\
\hline Observations & 378 & 378 & 378 & 378 & 378 & 378 & 378 & 378 \\
\hline
\end{tabular}

Note: The outcome variable is popular support. Estimated based on $y_{i, t}=\beta \Delta E P S_{i, t}+\theta X_{i, t}+\alpha_{i}+\gamma_{t}+\epsilon_{i, t}$. A coefficient of -0.2 is equivalent to a 10 percent decline in popular support from an increase in EPS from the 1 st to the 3 rd quartile of the EPS distribution. Standard deviations based on robust standard errors clustered at the country level in parentheses. $* * * * *, *$ denote significance at 1,5 and 10 percent, respectively. 
TABLE 6. THE EFFECT OF EPS CHANGES ON POPULAR SUPPORT MEDIATED BY FUEL PRICES, SHARE OF DIRTY ENERGY INDUSTRIES AND INITIALLEVEL OF EPS

\begin{tabular}{|c|c|c|c|c|}
\hline & (I) & (II) & (II) & (IV) \\
\hline deficit & $\begin{array}{c}0.039 * * * \\
(0.014)\end{array}$ & $\begin{array}{c}0.040^{* * * *} \\
(0.013)\end{array}$ & $\begin{array}{c}0.040^{* * *} \\
(0.009)\end{array}$ & $\begin{array}{c}0.039^{* * *} \\
(0.009)\end{array}$ \\
\hline elderly & $\begin{array}{c}0.165 * * * \\
(0.052)\end{array}$ & $\begin{array}{c}0.165 * * * \\
(0.050)\end{array}$ & $\begin{array}{c}0.163 * * * \\
(0.054)\end{array}$ & $\begin{array}{c}0.160^{* * *} \\
(0.051)\end{array}$ \\
\hline gdpr & $\begin{array}{c}0.063 * * \\
(0.028)\end{array}$ & $\begin{array}{c}0.061 * * \\
(0.028)\end{array}$ & $\begin{array}{c}0.063 * * * \\
(0.019)\end{array}$ & $\begin{array}{c}0.065^{* * *} \\
(0.019)\end{array}$ \\
\hline D.EPS x low_oilPrice & $\begin{array}{c}-0.029 \\
(0.272)\end{array}$ & & & \\
\hline D.EPS x high_oilPrice & $\begin{array}{c}-0.320 * * \\
(0.129)\end{array}$ & & & \\
\hline D.EPS x low_gasPrice & & $\begin{array}{c}0.222 \\
(0.301)\end{array}$ & & \\
\hline D.EPS x high_gasPrice & & $\begin{array}{c}-0.493 * * * \\
(0.170)\end{array}$ & & \\
\hline D.EPS x low_energyShare & & & $\begin{array}{l}-0.200 \\
(0.119)\end{array}$ & \\
\hline D.EPS x high_energyShare & & & $\begin{array}{c}-0.264^{* *} \\
(0.119)\end{array}$ & \\
\hline D.EPS x low_initialEPS & & & & $\begin{array}{c}-0.145 \\
(0.113)\end{array}$ \\
\hline D.EPS x high_initialEPS & & & & $\begin{array}{c}-0.321 * * * \\
(0.076)\end{array}$ \\
\hline Constant & $\begin{array}{c}0.634 \\
(0.633)\end{array}$ & $\begin{array}{c}0.628 \\
(0.614)\end{array}$ & $\begin{array}{l}-0.681 \\
(0.896)\end{array}$ & $\begin{array}{c}0.000 \\
(0.000)\end{array}$ \\
\hline Country FE & Yes & Yes & Yes & Yes \\
\hline Time FE & Yes & Yes & Yes & Yes \\
\hline $\mathrm{R}^{2}$ & 0.456 & 0.460 & 0.337 & 0.338 \\
\hline Observations & 370 & 370 & 370 & 366 \\
\hline
\end{tabular}

Note: The outcome variable is popular support. Estimated based on $y_{i, t}=F\left(z_{i, t}\right) *\left[\beta^{L} \Delta E P S_{i, t}+\theta^{L} X_{i, t}\right]+\left(1-F\left(z_{i, t}\right)\right) *$ $\left[\beta^{H} \Delta E P S_{i, t}+\theta^{H} X_{i, t}\right]+\alpha_{i}+\gamma_{t}+\epsilon_{i, t}$ with $F\left(z_{i, t}\right)=\frac{e^{-1.5 * z_{i, t}}}{1+e^{-1.5 * z_{i, t}}}$. A coefficient of -0.2 is equivalent to a 10 percent decline in popular support from an increase in EPS from the 1 st to the 3rd quartile of the EPS distribution. Standard deviations based on robust standard errors clustered at the country level in parentheses. $* * * * *, *$ denote significance at 1,5 and 10 percent, respectively. 
TABLE 7. THE EFFECT OF EPS CHANGES ON POPULAR SUPPORT MEDIATED BY INCOME SHARES

\begin{tabular}{|c|c|c|c|c|c|c|}
\hline & (I) & (II) & (III) & (IV) & $(\mathrm{V})$ & (VI) \\
\hline deficit & $\begin{array}{c}0.040 * * * \\
(0.014)\end{array}$ & $\begin{array}{c}0.040 * * * \\
(0.014)\end{array}$ & $\begin{array}{c}0.040 * * * \\
(0.014)\end{array}$ & $\begin{array}{c}0.034 * * * \\
(0.013)\end{array}$ & $\begin{array}{c}0.039 * * * \\
(0.014)\end{array}$ & $\begin{array}{c}0.040 * * * \\
(0.014)\end{array}$ \\
\hline elderly & $\begin{array}{c}0.142 * * \\
(0.058)\end{array}$ & $\begin{array}{c}0.144 * * \\
(0.059)\end{array}$ & $\begin{array}{c}0.145^{* *} \\
(0.059)\end{array}$ & $\begin{array}{c}0.126 * * \\
(0.059)\end{array}$ & $\begin{array}{c}0.143 * * \\
(0.058)\end{array}$ & $\begin{array}{c}0.147 * * \\
(0.058)\end{array}$ \\
\hline gdpr & $\begin{array}{c}0.071 * * \\
(0.035)\end{array}$ & $\begin{array}{c}0.071 * * \\
(0.035)\end{array}$ & $\begin{array}{c}0.071 * * \\
(0.035)\end{array}$ & $\begin{array}{c}0.108 * * * \\
(0.034)\end{array}$ & $\begin{array}{c}0.070 * * \\
(0.035)\end{array}$ & $\begin{array}{c}0.070 * * \\
(0.035)\end{array}$ \\
\hline D.EPS x low_top1share & $\begin{array}{c}0.023 \\
(0.192)\end{array}$ & & & & & \\
\hline D.EPS $\mathrm{x}$ high_top1share & $\begin{array}{l}-0.300 * \\
(0.156)\end{array}$ & & & & & \\
\hline D.EPS x low_top10share & & $\begin{array}{c}0.033 \\
(0.182)\end{array}$ & & & & \\
\hline D.EPS $\mathrm{x}$ high_top10share & & $\begin{array}{c}-0.320 * * \\
(0.155)\end{array}$ & & & & \\
\hline D.EPS x low_top20share & & & $\begin{array}{c}0.022 \\
(0.151)\end{array}$ & & & \\
\hline D.EPS $x$ high_top20share & & & $\begin{array}{c}-0.320 * * \\
(0.146)\end{array}$ & & & \\
\hline D.EPS x low_bot1share & & & & $\begin{array}{c}0.010 \\
(0.264)\end{array}$ & & \\
\hline D.EPS $x$ high_bot1share & & & & $\begin{array}{l}-0.254 \\
(0.314)\end{array}$ & & \\
\hline D.EPS x low_bot10share & & & & & $\begin{array}{l}-0.304 * \\
(0.156)\end{array}$ & \\
\hline D.EPS x high_bot10share & & & & & $\begin{array}{c}0.021 \\
(0.210)\end{array}$ & \\
\hline D.EPS x low_bot20share & & & & & & $\begin{array}{c}-0.352 * * \\
(0.150)\end{array}$ \\
\hline D.EPS x high_bot20share & & & & & & $\begin{array}{c}0.082 \\
(0.198)\end{array}$ \\
\hline Constant & $\begin{array}{c}0.278 \\
(0.907)\end{array}$ & $\begin{array}{c}0.252 \\
(0.912)\end{array}$ & $\begin{array}{c}0.227 \\
(0.918)\end{array}$ & $\begin{array}{c}0.442 \\
(0.928)\end{array}$ & $\begin{array}{c}0.269 \\
(0.912)\end{array}$ & $\begin{array}{c}0.208 \\
(0.907)\end{array}$ \\
\hline Country FE & Yes & Yes & Yes & Yes & Yes & Yes \\
\hline Time FE & Yes & Yes & Yes & Yes & Yes & Yes \\
\hline $\mathrm{R}^{2}$ & 0.513 & 0.513 & 0.513 & 0.524 & 0.513 & 0.514 \\
\hline Observations & 301 & 301 & 301 & 259 & 301 & 301 \\
\hline
\end{tabular}

Note: The outcome variable is popular support. Estimated based on $y_{i, t}=F\left(z_{i, t}\right) *\left[\beta^{L} \Delta E P S_{i, t}+\theta^{L} X_{i, t}\right]+\left(1-F\left(z_{i, t}\right)\right) *$ $\left[\beta^{H} \Delta E P S_{i, t}+\theta^{H} X_{i, t}\right]+\alpha_{i}+\gamma_{t}+\epsilon_{i, t}$ with $F\left(z_{i, t}\right)=\frac{e^{-1.5 * z_{i, t}}}{1+e^{-1.5 * z i, t}}$. A coefficient of -0.2 is equivalent to a 10 percent decline in popular support from an increase in EPS from the 1 st to the 3 rd quartile of the EPS distribution. Standard deviations based on robust standard errors clustered at the country level in parentheses. $* * * * * *$ denote significance at 1,5 and 10 percent, respectively. 
Table 7 (cont.). The effect of EPS changes on popular support mediated by inequality and social expenditure measures

\begin{tabular}{|c|c|c|c|c|c|}
\hline & (I) & (II) & (III) & (IV) & $(\mathrm{V})$ \\
\hline \multirow[t]{2}{*}{ deficit } & $0.038 * * *$ & $0.039 * * *$ & $0.033 * *$ & $0.033^{* *}$ & $0.034 * * *$ \\
\hline & $(0.014)$ & $(0.014)$ & $(0.013)$ & $(0.014)$ & $(0.013)$ \\
\hline \multirow[t]{2}{*}{ elderly } & 0.099 & 0.103 & $0.156 * *$ & $0.156^{* *}$ & $0.171 * *$ \\
\hline & $(0.094)$ & $(0.093)$ & $(0.062)$ & $(0.062)$ & $(0.070)$ \\
\hline \multirow[t]{2}{*}{ gdpr } & $0.057 * *$ & $0.057 * *$ & $0.048 * *$ & $0.047 * *$ & $0.050 *$ \\
\hline & $(0.026)$ & $(0.026)$ & $(0.024)$ & $(0.023)$ & $(0.027)$ \\
\hline \multirow[t]{2}{*}{ D.EPS x low_giniMRKT } & -0.066 & & & & \\
\hline & $(0.279)$ & & & & \\
\hline \multirow[t]{2}{*}{ D.EPS $x$ high_giniMRKT } & $-0.380 * *$ & & & & \\
\hline & $(0.170)$ & & & & \\
\hline \multirow[t]{2}{*}{ D.EPS $x$ low_giniNET } & & -0.006 & & & \\
\hline & & $(0.264)$ & & & \\
\hline \multirow[t]{2}{*}{ D.EPS $\mathrm{x}$ high_giniNET } & & $-0.402 * *$ & & & \\
\hline & & $(0.162)$ & & & \\
\hline \multirow[t]{2}{*}{ D.EPS x low_socExp } & & & $-0.504 * * *$ & & \\
\hline & & & $(0.167)$ & & \\
\hline \multirow[t]{2}{*}{ D.EPS x high_socExp } & & & -0.055 & & \\
\hline & & & $(0.143)$ & & \\
\hline \multirow[t]{2}{*}{ D.EPS x low_almpExp } & & & & $-0.483 * * *$ & \\
\hline & & & & $(0.158)$ & \\
\hline \multirow[t]{2}{*}{ D.EPS x high_almpExp } & & & & 0.084 & \\
\hline & & & & $(0.153)$ & \\
\hline \multirow[t]{2}{*}{ D.EPS x low_unempExp } & & & & & $-0.544 * * *$ \\
\hline & & & & & $(0.170)$ \\
\hline \multirow[t]{2}{*}{ D.EPS x high_unempExp } & & & & & 0.155 \\
\hline & & & & & $(0.218)$ \\
\hline \multirow[t]{2}{*}{ Constant } & 1.487 & 1.445 & 0.845 & 0.832 & 0.666 \\
\hline & $(1.149)$ & $(1.139)$ & $(0.734)$ & $(0.743)$ & $(0.827)$ \\
\hline Country FE & Yes & Yes & Yes & Yes & Yes \\
\hline Time FE & Yes & Yes & Yes & Yes & Yes \\
\hline $\mathrm{R}^{2}$ & 0.470 & 0.470 & 0.461 & 0.462 & 0.498 \\
\hline Observations & 326 & 326 & 334 & 334 & 321 \\
\hline
\end{tabular}


TABLE 8. THE EFFECT OF EPS CHANGES ON POPULAR SUPPORT USING INSTRUMENTAL VARIABLE REGRESSIONS

\begin{tabular}{lccccc}
\hline & $(\mathrm{I})$ & $(\mathrm{II})$ & $(\mathrm{II})$ & $(\mathrm{IV})$ & $(\mathrm{V})$ \\
\hline D.EPS & $-0.994 * * *$ & $-0.741^{* *}$ & $-0.635^{*}$ & $-1.047 *$ & $-0.879 * *$ \\
& $(0.386)$ & $(0.361)$ & $(0.341)$ & $(0.533)$ & $(0.377)$ \\
Country FE & & & & Yes & Yes \\
Time FE & Yes & Yes & Yes & Yes & Yes \\
Instrument: & & Yes & Yes & & \\
- Global term & eventsFlood & eventsFlood & majorHurric & peopleAffect & eventsWildfir \\
& & & edEQ & e \\
- Country term & coastLength & coastLengthF & cenDist & urbanCoastL & agriLandPC \\
1 st_stage coef. & $0.003 * * *$ & $0.003 * * *$ & $-7.552 * * *$ & $0.016 * * *$ & $9.58^{* * *}$ \\
& $(0.001)$ & $(0.000)$ & $(1.165)$ & $(0.004)$ & $(2.542)$ \\
1 st_stage F-Stat & 30.79 & 66.47 & 42.05 & 14.98 & 14.21 \\
Observations & 370 & 370 & 370 & 370 & 361 \\
\hline
\end{tabular}

Note: The outcome variable is popular support. Estimated based on $y_{i, t}=\beta \Delta E P S_{l, t}+\theta X_{i, t}+\alpha_{i}+\gamma_{t}+\epsilon_{i, t}$ with $\Delta E P S_{l, t}=$ $\vartheta S_{i, t}+\varphi X_{i, t}+\alpha_{i}+\gamma_{t}+v_{i, t}$. Controls from the baseline specification (table 3 column 1) are included. A coefficient of - 0.2 is equivalent to a 10 percent decline in popular support from an increase in EPS from the $1^{\text {st }}$ to the $3^{\text {rd }}$ quartile of the EPS distribution. Standard deviations based on robust standard errors clustered at the country level in parentheses. $* * *, * *, *$ denote significance at 1,5 and 10 percent, respectively. 
TABLE 9. VALIDITY OF IV (1). EFFECT OF INSTRUMENTS ON POPULAR SUPPORT

\begin{tabular}{|c|c|c|c|c|c|}
\hline & (I) & (II) & (III) & (IV) & $(\mathrm{V})$ \\
\hline D.EPS & $\begin{array}{c}-0.221 * * * \\
(0.078)\end{array}$ & $\begin{array}{c}-0.215 * * * \\
(0.079)\end{array}$ & $\begin{array}{c}-0.207 * * * \\
(0.080)\end{array}$ & $\begin{array}{c}-0.226 * * * \\
(0.079)\end{array}$ & $\begin{array}{c}-0.240 * * * \\
(0.081)\end{array}$ \\
\hline deficit & $\begin{array}{c}0.040 * * * \\
(0.014)\end{array}$ & $\begin{array}{c}0.039 * * * \\
(0.014)\end{array}$ & $\begin{array}{c}0.040 * * * \\
(0.014)\end{array}$ & $\begin{array}{c}0.040 * * * \\
(0.014)\end{array}$ & $\begin{array}{c}0.040 * * * \\
(0.014)\end{array}$ \\
\hline elderly & $\begin{array}{c}0.160 * * * \\
(0.050)\end{array}$ & $\begin{array}{c}0.164 * * * \\
(0.053)\end{array}$ & $\begin{array}{c}0.159 * * * \\
(0.050)\end{array}$ & $\begin{array}{c}0.163 * * * \\
(0.051)\end{array}$ & $\begin{array}{c}0.150 * * * \\
(0.048)\end{array}$ \\
\hline gdpr & $\begin{array}{c}0.062 * * \\
(0.028)\end{array}$ & $\begin{array}{l}0.063 * * \\
(0.029)\end{array}$ & $\begin{array}{l}0.061 * * \\
(0.028)\end{array}$ & $\begin{array}{c}0.063 * * \\
(0.029)\end{array}$ & $\begin{array}{c}0.064 * * \\
(0.029)\end{array}$ \\
\hline $\begin{array}{l}\text { eventsFlood* } \\
\text { coastLengthFB }\end{array}$ & $\begin{array}{l}-0.000 \\
(0.000)\end{array}$ & & & & \\
\hline $\begin{array}{l}\text { majorHurric* } \\
\text { cenDist }\end{array}$ & & $\begin{array}{c}0.000 \\
(0.000)\end{array}$ & & & \\
\hline $\begin{array}{l}\text { eventsFlood* } \\
\text { coastLengthWRI }\end{array}$ & & & $\begin{array}{l}-0.000 \\
(0.000)\end{array}$ & & \\
\hline $\begin{array}{l}\text { peopleAffectEQ* } \\
\text { urbanCoastLOG }\end{array}$ & & & & $\begin{array}{l}-0.000 \\
(0.000)\end{array}$ & \\
\hline $\begin{array}{l}\text { eventsWildfire* } \\
\text { agriLandPC }\end{array}$ & & & & & $\begin{array}{l}-0.000 \\
(0.000)\end{array}$ \\
\hline Constant & $\begin{array}{c}0.775 \\
(0.601)\end{array}$ & $\begin{array}{c}0.569 \\
(0.636)\end{array}$ & $\begin{array}{c}0.988 \\
(0.603)\end{array}$ & $\begin{array}{c}0.660 \\
(0.627)\end{array}$ & $\begin{array}{l}0.962 * \\
(0.566)\end{array}$ \\
\hline Country FE & Yes & Yes & Yes & Yes & Yes \\
\hline Time FE & Yes & Yes & Yes & Yes & Yes \\
\hline $\mathrm{R}^{2}$ & 0.456 & 0.456 & 0.459 & 0.456 & 0.458 \\
\hline Observations & 370 & 370 & 370 & 370 & 361 \\
\hline
\end{tabular}

Note: The outcome variable is popular support. Estimated based on $y_{i, t}=\beta \Delta E P S_{i, t}+\theta X_{i, t}+\alpha_{i}+\gamma_{t}+\epsilon_{i, t}$. The estimation is the same as in Table 3 column 1 (baseline) with the respective instrument as additional control. A coefficient of -0.2 is equivalent to a 10 percent decline in popular support from an increase in EPS from the 1 st to the 3rd quartile of the EPS distribution. Standard deviations based on robust standard errors clustered at the country level in parentheses. $* * *, * *$, denote significan ce at 1,5 and 10 percent, respectively. 
TABLE 10. VALIDITY OF IV (2). CORRELATION OF INSTRUMENTS ON BASELINE RESIDUALS

\begin{tabular}{|c|c|c|c|c|c|}
\hline & (I) & (II) & (III) & (IV) & $(\mathrm{V})$ \\
\hline \multirow[t]{2}{*}{ deficit } & 0.001 & -0.000 & 0.001 & 0.000 & 0.000 \\
\hline & $(0.014)$ & $(0.014)$ & $(0.014)$ & $(0.014)$ & $(0.014)$ \\
\hline \multirow[t]{2}{*}{ elderly } & -0.003 & 0.000 & -0.005 & -0.000 & -0.013 \\
\hline & $(0.050)$ & $(0.053)$ & $(0.050)$ & $(0.051)$ & $(0.048)$ \\
\hline \multirow[t]{2}{*}{ gdpr } & -0.000 & 0.000 & -0.002 & 0.000 & 0.001 \\
\hline & $(0.028)$ & $(0.029)$ & $(0.028)$ & $(0.029)$ & $(0.029)$ \\
\hline \multirow{2}{*}{$\begin{array}{l}\text { eventsFlood* } \\
\text { coastLengthFB }\end{array}$} & -0.000 & & & & \\
\hline & $(0.000)$ & & & & \\
\hline \multirow{2}{*}{$\begin{array}{l}\text { majorHurric* } \\
\text { cenDist }\end{array}$} & & 0.000 & & & \\
\hline & & $(0.000)$ & & & \\
\hline \multirow{2}{*}{$\begin{array}{l}\text { eventsFlood* } \\
\text { coastLengthWRI }\end{array}$} & & & -0.000 & & \\
\hline & & & $(0.000)$ & & \\
\hline \multirow{2}{*}{$\begin{array}{l}\text { peopleAffectEQ* } \\
\text { urbanCoastLOG }\end{array}$} & & & & -0.000 & \\
\hline & & & & $(0.000)$ & \\
\hline \multirow{2}{*}{$\begin{array}{l}\text { eventsWildfire* } \\
\text { agriLandPC }\end{array}$} & & & & & -0.000 \\
\hline & & & & & $(0.000)$ \\
\hline \multirow[t]{2}{*}{ Constant } & 0.116 & -0.090 & 0.329 & 0.002 & 0.303 \\
\hline & $(0.601)$ & $(0.636)$ & $(0.603)$ & $(0.627)$ & $(0.566)$ \\
\hline Country FE & Yes & Yes & Yes & Yes & Yes \\
\hline Time FE & Yes & Yes & Yes & Yes & Yes \\
\hline $\mathrm{R}^{2}$ & 0.00201 & 0.00259 & 0.00718 & 0.00141 & 0.00239 \\
\hline Observations & 370 & 370 & 370 & 370 & 361 \\
\hline
\end{tabular}


TABLE 11. VALIDITY OF IV (3). ROBUSTNESS OF IV ESTIMATION WITH ADDITIONAL CONTROLS

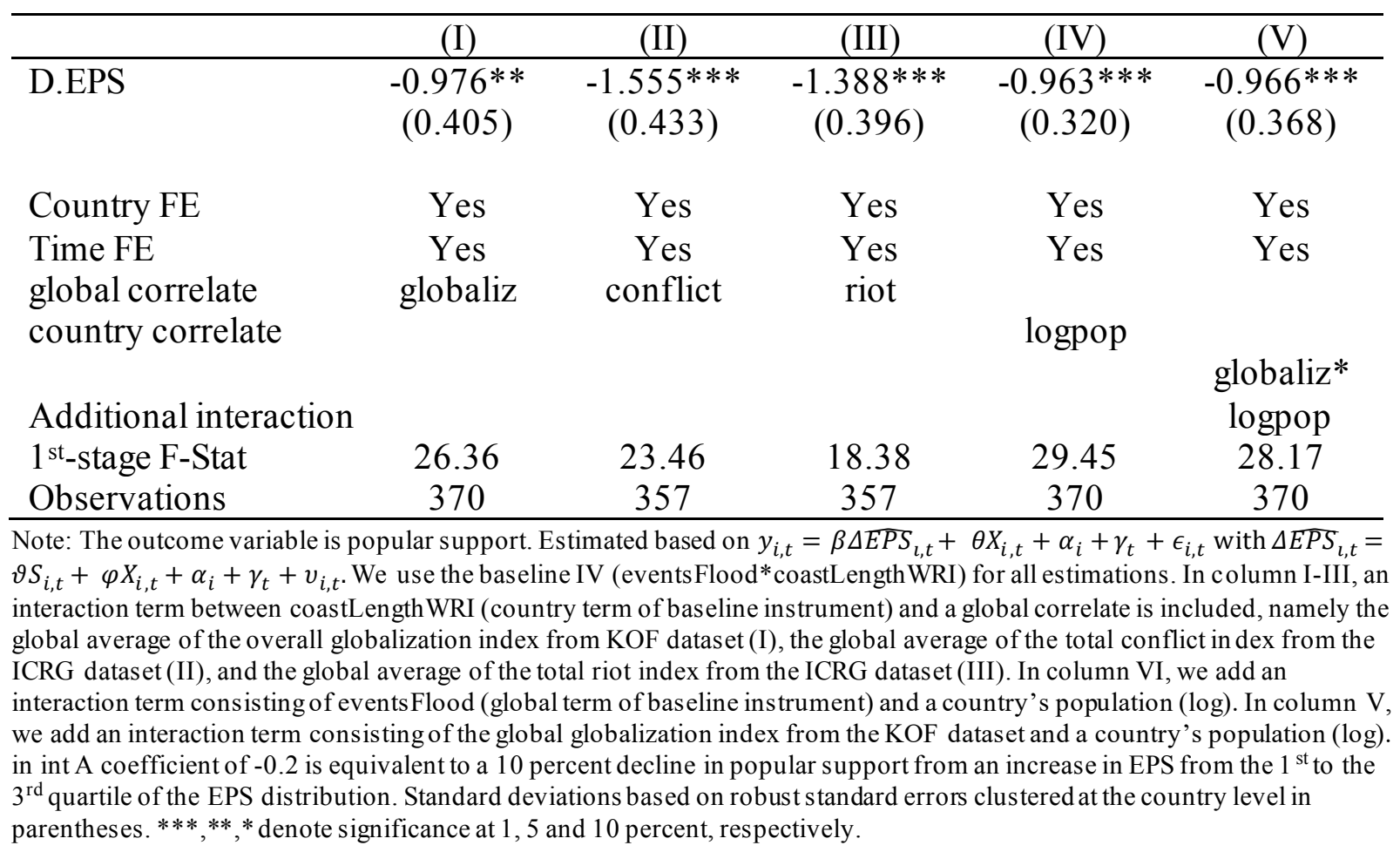


TABLE 12-1. THE EFFECT OF EPS CHANGES ON POPULAR SUPPORT MEDIATED BY FUEL PRICES (IV)

\begin{tabular}{lcccc}
\hline & $(\mathrm{I})$ & $(\mathrm{II})$ & $(\mathrm{III})$ & $(\mathrm{IV})$ \\
\hline D.EPS_low_oilPrice & 2.065 & & & \\
D.EPS_high_oilPrice & $(8.226)$ & & & \\
& & $-1.241^{* *}$ & & \\
D.EPS_low_gasPrice & & $(0.608)$ & -1.808 & \\
& & $(4.388)$ & $-1.184^{*}$ \\
D.EPS_high_gasPrice & & & $0.630)$ \\
& & & \\
Country FE & & & Yes \\
Time FE & Yes & Yes & Yes & Yes \\
1st-stage F-Stat & Yes & Yes & 2.52 & 12.82 \\
Observations & 0.02 & 12.161 & 370 & 370 \\
\hline
\end{tabular}

Note: The outcome variable is popular support. Controls from the baseline specification (table 3 column 1) are included. The instrument is peopleAffectEQ_urbanCoastLOG. A coefficient of -0.2 is equivalent to a 10 percent decline in popular support from an increase in EPS from the $1^{\text {st }}$ to the $3^{\text {rd }}$ quartile of the EPS distribution. Standard deviations based on robust standard errors clustered at the country level in parentheses. $* * *, * * *$ denote significance at 1,5 and 10 percent, respectively.

TABLE 12-2. THE EFFECT OF EPS CHANGES ON POPULAR SUPPORT MEDIATED BY SHARE OF DIRTY ENERGY INDUSTRIES AND INITIAL LEVEL OF EPS (IV)

\begin{tabular}{lcccc}
\hline & (I) & (II) & (III) & (IV) \\
\hline D.EPS_low_energyShare & $-1.374^{*}$ & & & \\
D.EPS_high_energyShare & $(0.773)$ & & & \\
& & $-3.675^{* *}$ & & \\
D.EPS_low_initialEPS & & $(1.769)$ & & \\
& & -3.530 & \\
D.EPS_high_initialEPS & & $(3.976)$ & $-1.343^{* * *}$ \\
& & & $(0.513)$ \\
Country FE & & & \\
Time FE & Yes & Yes & Yes & Yes \\
1st-stage F-Stat & Yes & Yes & Yes & Yes \\
Observations & 18.10 & 9.85 & 1.631 & 25.166 \\
\hline
\end{tabular}

Note: The outcome variable is popular support. Controls from the baseline specification (table 3 column 1 ) are included. The instrument is peopleAffectEQ_urbanCoastLOG. A coefficient of -0.2 is equivalent to a 10 percent decline in popular support from an increase in EPS from the $1^{\text {st }}$ to the $3^{\text {rd }}$ quartile of the EPS distribution. Standard deviations based on robust standard errors clustered at the country level in parentheses. ${ }^{* *}, * *, *$ denote significance at 1,5 and 10 percent, respectively 
Table 12-3: The effect of EPS changes on popular support mediated by income shares (IV)

\begin{tabular}{|c|c|c|c|c|c|c|}
\hline & (I) & (II) & (III) & (IV) & $(\mathrm{V})$ & $(\mathrm{VI})$ \\
\hline D.EPS_low_top1share & $\begin{array}{c}13.098 \\
(16.554)\end{array}$ & & & & & \\
\hline D.EPS_high_top 1 share & & $\begin{array}{c}-3.495 * * * \\
(0.561)\end{array}$ & & & & \\
\hline D.EPS_low_top 10 share & & & $\begin{array}{c}11.496 \\
(14.939)\end{array}$ & & & \\
\hline D.EPS_high_top 10share & & & & $\begin{array}{c}-4.482 * * * \\
(0.862)\end{array}$ & & \\
\hline D.EPS_low_top20share & & & & & $\begin{array}{c}7.378 \\
(7.012)\end{array}$ & \\
\hline D.EPS_high_top20share & & & & & & $\begin{array}{c}-5.500^{* * * *} \\
(1.546)\end{array}$ \\
\hline Country FE & Yes & Yes & Yes & Yes & Yes & Yes \\
\hline Time FE & Yes & Yes & Yes & Yes & Yes & Yes \\
\hline $1^{\text {st-stage F-Stat }}$ & 0.52 & 73.36 & 0.43 & 30.61 & 0.71 & 17.65 \\
\hline Observations & 301 & 301 & 301 & 301 & 301 & 301 \\
\hline
\end{tabular}

Note: The outcome variable is popular support. Controls from the baseline specification (table 3 column 1) are included. A coefficient of -0.2 is equivalent to a 10 percent decline in popular support from an increase in EPS from the $1^{\text {st }}$ to the $3^{\text {rd }}$ quartile of the EPS distribution. Standard deviations based on robust standard errors clustered at the country level in parentheses. $* * * * *, *$ denote significance at 1,5 and 10 percent, respectively.

TABLE 12-4. THE EFFECT OF EPS CHANGES ON POPULAR SUPPORT MEDIATED BY INCOME SHARES (IV)

\begin{tabular}{|c|c|c|c|c|c|c|}
\hline & (I) & (II) & (III) & (IV) & $(\mathrm{V})$ & $(\mathrm{VI})$ \\
\hline D.EPS_low_bot1share & $\begin{array}{c}-2.051 * * \\
(0.837)\end{array}$ & & & & & \\
\hline D.EPS_high_bot1share & & $\begin{array}{l}-0.458 \\
(0.577)\end{array}$ & & & & \\
\hline D.EPS_low_bot10share & & & $\begin{array}{c}-2.643 * * \\
(1.197)\end{array}$ & & & \\
\hline D.EPS_high_bot10share & & & & $\begin{array}{c}0.707 \\
(2.046)\end{array}$ & & \\
\hline D.EPS_low_bot20share & & & & & $\begin{array}{c}-4.291 * * * \\
(1.112)\end{array}$ & \\
\hline D.EPS_high_bot20share & & & & & & $\begin{array}{c}4.840 \\
(3.334)\end{array}$ \\
\hline Observations & 259 & 259 & 301 & 301 & 301 & 301 \\
\hline Country FE & Yes & Yes & Yes & Yes & Yes & Yes \\
\hline Time FE & Yes & Yes & Yes & Yes & Yes & Yes \\
\hline $1^{\text {st }}$-stage F-Stat & 8.42 & 29.84 & 25.02 & 1.14 & 24.82 & 1.02 \\
\hline Observations & 259 & 259 & 301 & 301 & 301 & 301 \\
\hline
\end{tabular}


TABLE 12-5. THE EFFECT OF EPS CHANGES ON POPULAR SUPPORT MEDIATED BY INEQUALITY (IV)

\begin{tabular}{|c|c|c|c|c|}
\hline & (I) & (II) & (III) & (IV) \\
\hline D.EPS_low_giniMRKT & $\begin{array}{c}1.454 \\
(1.876)\end{array}$ & & & \\
\hline D.EPS_high_giniMRKT & & $\begin{array}{c}-4.569 * * * \\
(1.757)\end{array}$ & & \\
\hline D.EPS_low_giniNET & & & $\begin{array}{c}4.748 \\
(3.315)\end{array}$ & \\
\hline D.EPS_high_giniNET & & & & $\begin{array}{c}-3.343 * * * \\
(0.852)\end{array}$ \\
\hline Country FE & Yes & Yes & Yes & Yes \\
\hline Time FE & Yes & Yes & Yes & Yes \\
\hline 1 st-stage F-Stat & 9.77 & 6.93 & 8.50 & 29.20 \\
\hline Observations & 326 & 326 & 326 & 326 \\
\hline
\end{tabular}

TABLE 12-6. THE EFFECT OF EPS CHANGES ON POPULAR SUPPORT MEDIATED BY SOCIAL EXPENDITURE (IV)

\begin{tabular}{|c|c|c|c|c|c|c|}
\hline & (I) & (II) & (III) & (IV) & $(\mathrm{V})$ & $(\mathrm{VI})$ \\
\hline D.EPS_low_socexp & $\begin{array}{c}-1.492 * * * \\
(0.523)\end{array}$ & & & & & \\
\hline D.EPS_high_socexp & & $\begin{array}{l}-2.694 \\
(4.886)\end{array}$ & & & & \\
\hline D.EPS_low_almpExp & & & $\begin{array}{c}-1.863 * \\
(1.037)\end{array}$ & & & \\
\hline D.EPS_high_almpExp & & & & $\begin{array}{c}10.620 \\
(21.066)\end{array}$ & & \\
\hline D.EPS_low_unempExp & & & & & $\begin{array}{c}-1.860 * * \\
(0.834)\end{array}$ & \\
\hline D.EPS_high_unempExp & & & & & & $\begin{array}{c}-15.330 \\
(12.759)\end{array}$ \\
\hline Country FE & Yes & Yes & Yes & Yes & Yes & Yes \\
\hline Time FE & Yes & Yes & Yes & Yes & Yes & Yes \\
\hline $1^{\text {st }}$-stage F-Stat & 44.32 & 2.54 & 76.26 & 0.38 & 36.28 & 1.18 \\
\hline Observations & 334 & 334 & 334 & 334 & 321 & 321 \\
\hline
\end{tabular}

Note: The outcome variable is popular support. Controls from the baseline specification (table 3 column 1) are included. A coefficient of -0.2 is equivalent to a 10 percent decline in popular support from an increase in EPS from the $1^{\text {st }}$ to the $3^{\text {rd }}$ quartile of the EPS distribution. Standard deviations based on robust standard errors clustered at the country level in parentheses. $* * *, * * * *$ denote significance at 1,5 and 10 percent, respectively. 
TABLE A1. THE EFFECT OF EPS CHANGES ON POPULAR SUPPORT - WALS AND BMA

\begin{tabular}{|c|c|c|c|c|}
\hline & (I) & (II) & (III) & (IV) \\
\hline \multirow[t]{3}{*}{ D.EPS } & $-0.269 * * *$ & $-0.249 * *$ & $-0.270 * * *$ & $-0.262 * *$ \\
\hline & $(0.088)$ & $(0.105)$ & $(0.088)$ & $(0.101)$ \\
\hline & {$[-3.07]$} & {$[-2.37]$} & {$[-3.05]$} & {$[-2.59]$} \\
\hline \multirow[t]{3}{*}{ deficit } & $0.022 *$ & 0.001 & 0.018 & 0.000 \\
\hline & $(0.011)$ & $(0.014)$ & $(0.018)$ & $(0.003)$ \\
\hline & [1.96] & {$[0.07]$} & [0.97] & {$[0.09]$} \\
\hline \multirow[t]{3}{*}{ elderly } & $0.143 * *$ & $0.160 *$ & $0.208 * * *$ & 0.126 \\
\hline & $(0.060)$ & $(0.095)$ & $(0.078)$ & $(0.130)$ \\
\hline & {$[2.40]$} & [1.69] & [2.67] & [0.97] \\
\hline \multirow[t]{3}{*}{ gdpr } & $0.035 * *$ & 0.023 & 0.033 & 0.002 \\
\hline & $(0.016)$ & $(0.020)$ & $(0.028)$ & $(0.008)$ \\
\hline & [2.19] & [1.19] & {$[1.16]$} & {$[0.20]$} \\
\hline \multirow[t]{3}{*}{ unemprate } & $-0.027 * *$ & $-0.050 * *$ & -0.031 & $-0.082 * * *$ \\
\hline & $(0.012)$ & $(0.019)$ & $(0.024)$ & $(0.017)$ \\
\hline & {$[-2.20]$} & {$[-2.59]$} & {$[-1.30]$} & {$[-4.86]$} \\
\hline \multirow[t]{3}{*}{ cpi } & -0.417 & -0.128 & -0.037 & -0.012 \\
\hline & $(0.370)$ & $(1.441)$ & $(0.203)$ & $(0.243)$ \\
\hline & {$[-1.13]$} & {$[-0.09]$} & {$[-0.18]$} & {$[-0.05]$} \\
\hline \multirow[t]{3}{*}{ voteshare } & & -0.003 & & -0.000 \\
\hline & & $(0.005)$ & & $(0.001)$ \\
\hline & & {$[-0.60]$} & & {$[-0.11]$} \\
\hline \multirow[t]{3}{*}{ taxrevenue } & 0.004 & 0.022 & 0.001 & 0.000 \\
\hline & $(0.026)$ & $(0.041)$ & $(0.009)$ & $(0.007)$ \\
\hline & {$[0.16]$} & {$[0.55]$} & {$[0.09]$} & {$[0.03]$} \\
\hline \multirow[t]{3}{*}{ constant } & 0.759 & 6.760 & 0.886 & 3.982 \\
\hline & $(1.355)$ & $(4.769)$ & $(1.165)$ & $(4.329)$ \\
\hline & {$[0.56]$} & {$[1.42]$} & {$[0.76]$} & {$[0.92]$} \\
\hline Model Type & WALS & WALS & BMA & BMA \\
\hline Country FE & Yes & Yes & Yes & Yes \\
\hline Time FE & Yes & Yes & Yes & Yes \\
\hline Observations & 349 & 232 & 349 & 232 \\
\hline
\end{tabular}

Note: The outcome variable is popular support. The estimates are the results of WALS (Column 1 and 2) and BMA regressions (Column 3 and 4). Column 1 and 3 use the control variables from Table 3 Column 6 without vote share (vote share was dropped in order to make the sample as large as possible). Column 2 and 4 use the control variables from Table 3 Column 6 (including vote share) plus the following additional covariates: share of green parties in parliament, partisanship of chief exec utive of government, government fractionalization index, numbers of years left in current term, margin of majority, Herfindahl index of opposition parties, index of democratic accountability, index of bureaucratic quality, index of civil disorder, index of legis lative strength, tax wedge from national accounts, average tax wedge for one-earner married couple, net household income for couple with two children (levels and changes). A coefficient of -0.2 is equivalent to a 10 percent decline in popular support from an increase in EPS from the $1^{\text {st }}$ to the $3^{\text {rd }}$ quartile of the EPS distribution. Standard errors in parentheses, t statistics in brackets. $* * *, * * *$ denote significance at 1,5 and 10 percent, respectively. 
TABLE A2. THE EFFECT OF EPS CHANGES ON VOTE SHARE

\begin{tabular}{|c|c|c|c|c|c|}
\hline & (I) & (II) & (III) & (IV) & (V) \\
\hline D.EPS & $\begin{array}{r}-6.908^{*} \\
(3.556)\end{array}$ & $\begin{array}{l}-6.901 * \\
(3.495)\end{array}$ & $\begin{array}{l}-6.368 * \\
(3.658)\end{array}$ & $\begin{array}{c}-9.042 * * * \\
(2.350)\end{array}$ & $\begin{array}{c}-12.341 * * * \\
(2.833)\end{array}$ \\
\hline L.voteshare & $\begin{array}{c}-0.391 * * * \\
(0.086)\end{array}$ & $\begin{array}{c}-0.406^{* * *} \\
(0.084)\end{array}$ & $\begin{array}{c}-0.494 * * * \\
(0.074)\end{array}$ & $\begin{array}{c}-0.604^{* * * *} \\
(0.074)\end{array}$ & $\begin{array}{c}-0.669^{* * * *} \\
(0.082)\end{array}$ \\
\hline deficit & $\begin{array}{c}0.686 \\
(0.675)\end{array}$ & $\begin{array}{c}0.488 \\
(0.768)\end{array}$ & $\begin{array}{c}0.514 \\
(0.727)\end{array}$ & $\begin{array}{c}0.605 \\
(0.673)\end{array}$ & $\begin{array}{c}0.366 \\
(0.737)\end{array}$ \\
\hline elderly & $\begin{array}{l}-0.574 \\
(1.608)\end{array}$ & $\begin{array}{l}-0.745 \\
(1.671)\end{array}$ & $\begin{array}{c}0.555 \\
(1.193)\end{array}$ & $\begin{array}{c}-3.340^{* *} \\
(1.153)\end{array}$ & $\begin{array}{l}-2.750 \\
(1.657)\end{array}$ \\
\hline gdpr & $\begin{array}{l}1.481^{*} \\
(0.827)\end{array}$ & $\begin{array}{l}1.440^{*} \\
(0.803)\end{array}$ & $\begin{array}{c}1.585^{* *} \\
(0.709)\end{array}$ & $\begin{array}{c}1.553^{* *} \\
(0.620)\end{array}$ & $\begin{array}{l}1.384^{*} \\
(0.732)\end{array}$ \\
\hline unemprate & & $\begin{array}{l}-0.451 \\
(0.429)\end{array}$ & $\begin{array}{l}-0.210 \\
(0.384)\end{array}$ & $\begin{array}{c}-1.032 * * \\
(0.392)\end{array}$ & $\begin{array}{c}-1.189 * * \\
(0.523)\end{array}$ \\
\hline срі & & & $\begin{array}{c}31.725^{* * * *} \\
(11.205)\end{array}$ & $\begin{array}{c}19.024 \\
(15.291)\end{array}$ & $\begin{array}{l}27.858^{*} \\
(15.076)\end{array}$ \\
\hline taxrevenue & & & & $\begin{array}{c}0.358 \\
(0.980)\end{array}$ & $\begin{array}{c}0.112 \\
(1.180)\end{array}$ \\
\hline finref_index & & & & & $\begin{array}{l}-20.690 \\
(26.580)\end{array}$ \\
\hline product_index & & & & & $\begin{array}{c}0.576 \\
(7.794)\end{array}$ \\
\hline current_index & & & & & $\begin{array}{c}26.211 \\
(19.451)\end{array}$ \\
\hline capital_index & & & & & $\begin{array}{c}-65.451^{* * *} \\
(22.230)\end{array}$ \\
\hline labor_index & & & & & $\begin{array}{c}-7.841 \\
(28.372)\end{array}$ \\
\hline Constant & $\begin{array}{c}15.837 \\
(29.826)\end{array}$ & $\begin{array}{c}0.956 \\
(27.186)\end{array}$ & $\begin{array}{l}-50.243 * \\
(27.857)\end{array}$ & $\begin{array}{c}0.000 \\
(0.000)\end{array}$ & $\begin{array}{c}0.000 \\
(0.000)\end{array}$ \\
\hline Country FE & Yes & Yes & Yes & Yes & Yes \\
\hline Time FE & Yes & Yes & Yes & Yes & Yes \\
\hline R2 & 0.421 & 0.428 & 0.498 & 0.660 & 0.701 \\
\hline Observations & 109 & 109 & 109 & 80 & 80 \\
\hline
\end{tabular}

Note: The outcome variable is vote share of the incumbent. Estimated based on $y_{i, t}=\beta \Delta E P S_{i, t}+\theta X_{i, t}+\alpha_{i}+\gamma_{t}+\epsilon_{i, t}$. Standard deviations based on Driscoll-Kraay standard errors with two lags in parentheses. ***,**,* denote significance at 1,5 and 10 percent, respectively. 
TABLE A3. THE EFFECT OF EPS CHANGES ON POPULAR SUPPORT MEDIATED BY SOCIAL EXPENDITURE TYPES

\begin{tabular}{|c|c|c|c|c|c|}
\hline & (I) & (II) & (III) & (IV) & (V) \\
\hline deficit & $\begin{array}{c}0.032 * * \\
(0.014)\end{array}$ & $\begin{array}{c}0.034 * * * \\
(0.013)\end{array}$ & $\begin{array}{c}0.031 * * \\
(0.013)\end{array}$ & $\begin{array}{c}0.032 * * \\
(0.014)\end{array}$ & $\begin{array}{c}0.032 * * \\
(0.013)\end{array}$ \\
\hline elderly & $\begin{array}{c}0.153 * * \\
(0.061)\end{array}$ & $\begin{array}{c}0.155 * * \\
(0.061)\end{array}$ & $\begin{array}{c}0.143 * * \\
(0.058)\end{array}$ & $\begin{array}{c}0.156 * * \\
(0.062)\end{array}$ & $\begin{array}{c}0.155 * * \\
(0.062)\end{array}$ \\
\hline gdprb & $\begin{array}{c}0.048 * * \\
(0.024)\end{array}$ & $\begin{array}{c}0.048 * * \\
(0.024)\end{array}$ & $\begin{array}{c}0.050 * * \\
(0.024)\end{array}$ & $\begin{array}{c}0.048 * * \\
(0.023)\end{array}$ & $\begin{array}{c}0.049 * * \\
(0.024)\end{array}$ \\
\hline D.EPS_low_famExp & $\begin{array}{c}-0.408 * * \\
(0.195)\end{array}$ & & & & \\
\hline D.EPS_high_famExp & $\begin{array}{l}-0.139 \\
(0.136)\end{array}$ & & & & \\
\hline D.EPS_low_healthExp & & $\begin{array}{c}-0.894 * * * \\
(0.260)\end{array}$ & & & \\
\hline D.EPS_high_healthExp & & $\begin{array}{c}0.078 \\
(0.147)\end{array}$ & & & \\
\hline D.EPS_low_houseExp & & & $\begin{array}{l}-0.226 \\
(0.169)\end{array}$ & & \\
\hline D.EPS_high_houseExp & & & $\begin{array}{l}-0.285 \\
(0.192)\end{array}$ & & \\
\hline D.EPS_low_incapExp & & & & $\begin{array}{c}-0.348 * * * \\
(0.115)\end{array}$ & \\
\hline D.EPS_high_incapExp & & & & $\begin{array}{l}-0.145 \\
(0.147)\end{array}$ & \\
\hline D.EPS_low_oldExp & & & & & $\begin{array}{c}-0.380 * * \\
(0.188)\end{array}$ \\
\hline D.EPS_high_oldExp & & & & & $\begin{array}{l}-0.124 \\
(0.167)\end{array}$ \\
\hline Constant & $\begin{array}{c}0.875 \\
(0.735)\end{array}$ & $\begin{array}{c}0.849 \\
(0.734)\end{array}$ & $\begin{array}{c}0.987 \\
(0.693)\end{array}$ & $\begin{array}{c}0.833 \\
(0.737)\end{array}$ & $\begin{array}{c}0.849 \\
(0.739)\end{array}$ \\
\hline Country FE & Yes & Yes & Yes & Yes & Yes \\
\hline Time FE & Yes & Yes & Yes & Yes & Yes \\
\hline $\mathrm{R}^{2}$ & 0.458 & 0.471 & 0.459 & 0.458 & 0.458 \\
\hline Observations & 334 & 334 & 325 & 334 & 334 \\
\hline
\end{tabular}


TABLE A4. THE EFFECT OF EPS CHANGES ON VOTE SHARE USING INSTRUMENTAL VARIABLE REGRESSIONS

\begin{tabular}{|c|c|c|c|c|c|}
\hline & (I) & (II) & (II) & (IV) & (V) \\
\hline D.EPS & $\begin{array}{c}-6.944 \\
(11.215)\end{array}$ & $\begin{array}{c}-15.049 * \\
(8.404)\end{array}$ & $\begin{array}{l}-7.467 \\
(9.378)\end{array}$ & $\begin{array}{l}-14.614 \\
(17.845)\end{array}$ & $\begin{array}{l}-8.173 \\
(8.903)\end{array}$ \\
\hline Country FE & Yes & Yes & Yes & Yes & Yes \\
\hline $\begin{array}{l}\text { Time FE } \\
\text { Instrument: }\end{array}$ & Yes & Yes & Yes & Yes & Yes \\
\hline - Global term & eventsFlood & eventsFlood & majorHurric & $\begin{array}{c}\text { peopleAffect } \\
\text { edEQ }\end{array}$ & $\begin{array}{c}\text { eventsWildfir } \\
\mathrm{e}\end{array}$ \\
\hline - Country term & $\begin{array}{c}\text { coastLength } \\
\text { WRI }\end{array}$ & $\begin{array}{c}\text { coastLengthF } \\
\text { B }\end{array}$ & cenDist & $\begin{array}{c}\text { urbanCoastL } \\
\text { OG }\end{array}$ & agriLandPC \\
\hline $1^{\text {st-stage coef. }}$ & $\begin{array}{c}0.0027 * * \\
(0.001)\end{array}$ & $\begin{array}{c}-11.18 * * * \\
(1.950)\end{array}$ & $\begin{array}{c}0.0022 * * \\
(0.001)\end{array}$ & $\begin{array}{r}-0.0184 \\
(0.034)\end{array}$ & $\begin{array}{c}25.943 \\
(17.215)\end{array}$ \\
\hline $1^{\text {st-stage F-Stat }}$ & 5.416 & 32.865 & 6.997 & 0.3 & 2.271 \\
\hline Observations & 81 & 81 & 81 & 81 & 79 \\
\hline
\end{tabular}

Note: The outcome variable is vote share. Estimated based on $y_{i, t}=\beta \Delta E P S_{l, t}+\theta X_{i, t}+\alpha_{i}+\gamma_{t}+\epsilon_{i, t}{\text { with } \triangle E P S_{l, t}}=$ $\vartheta S_{i, t}+\varphi X_{i, t}+\alpha_{i}+\gamma_{t}+v_{i, t}$. Controls from the baseline specification (table 3 column 1) are included. Standard deviations based on Driscoll-Kraay standard errors with two lags in parentheses. ***,**,* denote significance at 1,5 and 10 percent, respectively. 
TABLE A5. THE EFFECT OF EPS CHANGES ON POPULAR SUPPORT MEDIATED BY IDEOLOGY

\begin{tabular}{|c|c|c|c|c|c|c|}
\hline & (I) & (II) & (III) & (IV) & (V) & (VI) \\
\hline \multirow[t]{2}{*}{ D.EPS*left } & $-0.420^{* *}$ & $-0.437 * *$ & $-0.440 * *$ & $-0.468 * *$ & $-0.498 * *$ & $-0.473 * *$ \\
\hline & $(0.185)$ & $(0.179)$ & $(0.180)$ & $(0.207)$ & $(0.210)$ & $(0.208)$ \\
\hline \multirow[t]{2}{*}{ D.EPS*center } & -0.190 & $-0.231 * *$ & $-0.239 * *$ & $-0.243 * *$ & $-0.265^{* *}$ & $-0.247 * *$ \\
\hline & $(0.119)$ & $(0.115)$ & $(0.117)$ & $(0.119)$ & $(0.121)$ & $(0.114)$ \\
\hline \multirow[t]{2}{*}{ D.EPS*right } & 0.175 & 0.169 & 0.168 & 0.140 & 0.060 & 0.048 \\
\hline & $(0.190)$ & $(0.170)$ & $(0.169)$ & $(0.177)$ & $(0.157)$ & $(0.148)$ \\
\hline \multirow[t]{2}{*}{ deficit } & $0.036^{* *}$ & 0.021 & 0.019 & 0.017 & $0.026^{* *}$ & $0.027 * *$ \\
\hline & $(0.016)$ & $(0.016)$ & $(0.016)$ & $(0.017)$ & $(0.013)$ & $(0.013)$ \\
\hline \multirow[t]{2}{*}{ elderly } & 0.071 & 0.063 & 0.081 & 0.079 & 0.105 & 0.097 \\
\hline & $(0.097)$ & $(0.093)$ & $(0.094)$ & $(0.096)$ & $(0.096)$ & $(0.093)$ \\
\hline \multirow[t]{2}{*}{ gdpr } & $0.075^{* *}$ & $0.056^{*}$ & $0.061^{*}$ & 0.057 & 0.047 & 0.037 \\
\hline & $(0.031)$ & $(0.033)$ & $(0.035)$ & $(0.037)$ & $(0.040)$ & $(0.034)$ \\
\hline \multirow[t]{2}{*}{ unemprate } & & $-0.050 * * *$ & $-0.048^{* * *}$ & $-0.046^{* *}$ & $-0.050^{* * *}$ & $-0.054^{* *}$ \\
\hline & & $(0.016)$ & $(0.018)$ & $(0.019)$ & $(0.018)$ & $(0.024)$ \\
\hline \multirow[t]{2}{*}{ cpi } & & & 0.501 & 0.416 & 0.205 & -0.652 \\
\hline & & & (0.309) & $(0.337)$ & $(0.314)$ & $(0.558)$ \\
\hline \multirow[t]{2}{*}{ voteshare } & & & & 0.007 & 0.006 & 0.004 \\
\hline & & & & $(0.006)$ & $(0.006)$ & $(0.005)$ \\
\hline \multirow[t]{2}{*}{ taxrevenue } & & & & & -0.041 & -0.042 \\
\hline & & & & & $(0.047)$ & $(0.047)$ \\
\hline \multirow[t]{2}{*}{ finref_index } & & & & & & 0.169 \\
\hline & & & & & & (1.851) \\
\hline \multirow[t]{2}{*}{ product_index } & & & & & & -0.542 \\
\hline & & & & & & $(0.719)$ \\
\hline \multirow[t]{2}{*}{ current_index } & & & & & & 1.828 \\
\hline & & & & & & (1.556) \\
\hline \multirow[t]{2}{*}{ capital_index } & & & & & & 0.514 \\
\hline & & & & & & (1.170) \\
\hline \multirow[t]{2}{*}{ labor_index } & & & & & & 2.562 \\
\hline & & & & & & $(2.829)$ \\
\hline \multirow[t]{2}{*}{ Constant } & 1.856 & $2.270^{* *}$ & 1.655 & 1.777 & 2.622 & -0.278 \\
\hline & (1.184) & (1.124) & $(1.210)$ & $(1.230)$ & (1.713) & $(2.527)$ \\
\hline Country FE & Yes & Yes & Yes & Yes & Yes & Yes \\
\hline Time FE & Yes & Yes & Yes & Yes & Yes & Yes \\
\hline $\mathrm{R}^{2}$ & 0.466 & 0.484 & 0.488 & 0.487 & 0.521 & 0.535 \\
\hline Observations & 305 & 305 & 305 & 294 & 289 & 289 \\
\hline
\end{tabular}

Note: The outcome variable is popular support. Estimated based on $y_{i, t}=\beta \Delta E P S_{i, t}+\theta X_{i, t}+\alpha_{i}+\gamma_{t}+\epsilon_{i, t}$. A coefficient of 0.2 is equivalent to a 10 percent decline in popular support from an increase in EPS from the $1 \mathrm{st}$ to the 3 rd quartile of the EPS distribution. Standard deviations based on robust standard errors clustered at the country level in parentheses. ${ }^{* * *, * *}, *$ den ote significance at 1,5 and 10 percent, respectively. 